Secrecy and the Impact of Mandatory IFRS Adoption on Earnings Quality in Europe

Muhammad Nurul Houqe

Victoria Business School

Victoria University of Wellington, New Zealand

Reza M. Monem

Griffith Business School

Griffith University, Australia

Mohammad Tareq

School of Accounting

RMIT University, Australia

Tony van Zijl

Victoria Business School

Victoria University of Wellington, New Zealand

This version: 7 August 2016 


\title{
Secrecy and the Impact of Mandatory IFRS Adoption on Earnings Quality in Europe
}

\begin{abstract}
This study examines how differences in national culture, as indicated by financial secrecy, affect the impact of mandatory adoption of IFRS on earnings quality across the countries of Europe. Using 24,034 firm-year observations from 16 European countries over the period 1998 - 2014, we find that the higher the level of secrecy in a country the lower the level of earnings quality of firms, as measured by signed abnormal accruals. We find that mandatory adoption of IFRS improves earnings quality in all countries. However, our study indicates that the impact of mandatory adoption of IFRS on earnings quality is stronger the higher the level of secrecy in a country. Our evidence thus helps to explain the different impacts of IFRS adoption on earnings quality across different jurisdictions.
\end{abstract}

Key Words: Earnings quality; national culture; secrecy; mandatory IFRS adoption; signed abnormal accruals.

This version: 7 August 2016 


\section{Secrecy and the Impact of Mandatory IFRS Adoption on Earnings Quality in Europe}

\section{Introduction}

As at June 2016, over 130 countries around the world have adopted International Financial Reporting Standards (IFRS) in one form or another (Deloite, 2016). These countries reflect a wide range of different cultures and institutional settings. Ball, Robin and Wu (2003) and Ball (2006) suggest that differences in institutional environment are likely to lead to differences in quality of financial reporting even where the same accounting standards are applied. Specifically, there is mixed evidence on the quality of financial reporting following IFRS adoption. While several studies document improved earnings quality following IFRS adoption (e.g., Barth, Landsman and Lang, 2008; Leuz, Nanda and Wysocki, 2003), others provide evidence of either no improvement or decline in earnings quality (e.g., Gebhardt and Novotny-Farkas, 2011; Jeanjean and Stowlowy, 2008). In this paper, we investigate the effect of national culture, as indicated by secrecy, on earnings quality following IFRS adoption.

Our study is motivated by strong evidence that culture plays an important role in financial reporting choices and quality (Callen, Morel and Richardson, 2010; Desender, Castro and Leon, 2011; Doupnik and Perera, 2009; Feleaga, Dragomir and Fleaga, 2010; Salter and Niswander, 1995; Gray and Vint, 1995; Gray, 1988). Given that the vast majority of the countries that have adopted IFRS have diverse national cultures (in addition to other institutional differences), it is likely that IFRS adoption will not have the same effect on earnings quality across all these countries. We are also motivated by lack of any evidence on the interaction between national culture and IFRS adoption. Thus our study may inform the debate on why earnings quality varies across countries that have adopted IFRS. 
We analyse 24,034 firm year observations across 16 countries over the period 19982014. We measure earning quality by the magnitude of signed abnormal accruals and financial secrecy by the Financial Secrecy Index (FSI) of the National Tax Justice Network (2015). We find that the higher the level of secrecy in a country the lower the level of earnings quality of firms. We find that mandatory adoption of IFRS improves earnings quality in all countries. However, our study also indicates that the impact of mandatory adoption of IFRS on earnings quality is stronger the higher the level of secrecy in a country. Our analysis includes controls at the firm level for audit quality, sales, capital structure, growth, cash flow from operations, and losses, and at the country level for investor protection. Our results are robust to several sensitivity tests including alternative measures for earnings quality, secrecy, investor protection, and also to alternative sample compositions.

Our study makes a single but important contribution to the cross-country literature on IFRS adoption. Specifically, our study provides evidence of how IFRS adoption can have differential impact on earnings quality depending on national culture, as indicated by the level of financial secrecy. Although the differential impact of IFRS adoption on earnings quality due to differences in institutional environments such as investor protection and enforcement of accounting standards have been documented, our study is the first one to document an interaction between IFRS adoption and national culture.

The remainder of our paper is organized as follows. In section 2 we set out the theoretical framework and in section 3 the hypothesis development. In section 4, we present the research design and in section 5 the sample selection process and results. Finally, our conclusion is presented in section 6 


\section{Theoretical framework}

Many researchers have addressed issues related to the importance of macro level factors and their impact on economic activity. Macro level factors include investor protection, taxation system, judicial independence and the legal system, the financing system, and national culture. Several studies report that the legal regime of a country can influence the level of financial disclosures and accounting quality (Ball, Kothari and Robin, 2000; Jaggi and Low, 2000). The investor protection regime is also a factor influencing earnings quality because low earnings quality is less likely to occur in countries with stronger investor protection. For example, Hung (2000), using a large sample of firm year observations across 21 countries, finds that there is a negative relation between accrual accounting and the value relevance of financial statements in countries with weak investor protection regime. In addition, Leuz et al. (2003) using data from 31 countries show that countries with 'arm's length' institutional features have lower levels of earnings management than do countries with 'insider' institutional characteristics.

Teets (2002) argues that earnings quality is a multidimensional concept affected by at least three sets of decisions: decisions made by standard setters, choices made by management on accounting methods and the judgments and estimates made by management in implementing the selected methods. In order to evaluate earnings quality, prior studies typically consider the magnitude of signed abnormal accruals (Francis and Wang, 2008; Houqe, van Zijl, Dunstan and Karim, 2012). DeFond and Park (2001) use signed abnormal accruals measure and find a higher earnings response coefficient where abnormal accruals suppress the magnitude of earnings surprises, and a lower earnings response coefficient where abnormal accruals exaggerate the magnitude of earnings surprise. Francis and Wang (2008) also use signed abnormal accruals analysis to detect the relation between investor 
protection and earning quality. Jeter and Shivakumar (1999) investigate the effectiveness of using estimated abnormal accruals in detecting event-specific earnings management. They find that the power of accruals models in detecting event-specific management varies across quarters depending on managerial incentives and opportunities for earnings management.

\subsection{Culture and accounting}

National culture is considered to be a factor that influences the accounting system of a country. Hofstede (1980) found four cultural dimensions that can be used to describe the similarities and differences in cultures: individualism, power distance, uncertainty avoidance and masculinity. Based on Hofstede's cultural dimensions, Gray (1988) defined four widely recognized accounting values - professionalism, uniformity, conservatism and secrecy - and developed a model linking culture and these accounting values. Gray (1988, p.8) defines secrecy (as opposed to transparency) as "a preference for confidentiality and the restriction of disclosure of information about the business only to those who are closely involved with its management and financing as opposed to a more transparent, open and publicly accountable approach" and argues that a high level of uncertainty avoidance and power distance and a low level of individualism and masculinity is consistent with a high level of secrecy. In particular, for secrecy in respect of accounting, the cultural values of uncertainty avoidance and individualism have the greatest relevance.

Several studies have examined Gray's model and the relationship between Hofstede's culture value and national accounting systems. Salter and Niswander (1995) tested Gray's model and found it best at explaining actual financial reporting practices but weak in explaining legal and professional structures. Furthermore, they showed that the development of financial markets and levels of taxation enhance the explanations offered by Gray (1988). 
Sudarwan and Fogarty (1996) showed that there is a relation between change in culture values and change in accounting. In addition, Gray and Vint (1995) tested the effect of culture on accounting disclosure and found that individualism is positively related to disclosure but that power distance and uncertainty avoidance are negatively related to accounting information disclosure.

Accounting is clearly affected by organizational and national culture (Asiyaban and Abdoli, 2012). For example, Jaggi and Low (2000) research the impact of culture, market forces, and legal system on financial disclosures. They find that the relationship between the cultural value of individualism and financial disclosures is significant for code law countries but that uncertainty avoidance and power distance have insignificant effects on financial disclosure in both common law and code law countries. Given that the level of financial disclosure by firms in common law countries is higher than that in code law countries the influence of cultural values on financial disclosures by firms will be less important in common law countries. Based on data from 47 countries and after controlling for economic development, Richardson (2008) indicates that the higher the level of uncertainty avoidance and the lower level of the individualism, the higher is the level of tax evasion across countries. In addition, Tsakumis, Curatola and Porcano (2007) investigate the relation between national cultural dimensions and tax evasion across 50 countries and find that uncertainty avoidance is positively associated with tax evasion levels. Higher individualism is associated with lower tax evasion across countries. 


\subsection{IFRS adoption and earnings quality}

The aim of the International Accounting Standards Board (IASB) is to develop a single set of high quality, understandable, enforceable and globally accepted financial reporting standards based upon clearly articulated principles (IASB, 2012). Armstrong, Barth, Jagolinzer and Riedl (2010) investigate the equity market reaction to adoption of IFRS in Europe. The results show that European investors and firms reacted positively to the adoption of IFRS and information quality improved with lower information asymmetry in the post-adoption period.

The adoption of a common set of accounting standards can improve earnings quality because IFRS reporting increases transparency. Additionally, financial statement comparability helps investors to evaluate potential investment in foreign capital market more easily and, therefore, risk is reduced (Doupnik and Perera, 2009, p.71). One set of global accounting standards would reduce the cost of preparing worldwide consolidated financial statements and also the cost of reconciliation between different standards (Doupnik and Perera, 2009, p.71). Horton and and Serafeim (2010) test for differences in forecast errors before and after mandatory adoption of IFRS. They find that IFRS improves the information environment. Specifically, after mandatory adoption of IFRS, forecast accuracy and other measures of the information environment increase significantly. Similarly, for voluntary adoption. Another advantage of IFRS adoption is to increase market liquidity and decrease cost of capital for firms (Daske, Hail, Leuz and Verdi, 2008). However, Daske et al. (2008) point out that the capital- market benefits occur only in countries with strong enforcement regimes and in countries where the institutional environment provides strong incentives to firms to be transparent. Although the adoption of IFRS eliminates national accounting differences in these countries, earnings quality remains different across countries (Houqe et al. 2012). This is so because culture, legal system and other factors can lead to different 
interpretations of standards and different levels of compliance across countries, leading to the differences in financial statements (Doupnik and Perera, 2009, p.105).

Research by Liu, Yao, Hu and Liu (2011) considers the impact of IFRS on accounting quality in China. China is a special case where the markets are disciplined mainly by the regulators rather than market mechanisms. Using a sample of 870 firms over the 2005 to 2008 period, Liu et al. (2011) find that accounting quality is improved after the mandatory adoption of IFRS convergent standards in China with decreased level of earnings management and earnings smoothing and increased value relevance to stock price and return. Chua, Cheong and Gould (2012) examine the impact of IFRS adoption on accounting quality in the context of the Australian capital market by focusing on earnings management, timely loss recognition and value relevance. Chua et al. (2012) find that mandatory adoption of IFRS has generally enhanced earnings quality, especially in the form of less earnings smoothing behaviour. In addition, there is a higher probability that larger losses are reported in the postadoption period than in the pre-adoption period; the value relevance of accounting data improved after IFRS adoption. All of the results support there having been an improvement in accounting quality after Australian listed companies moved from Australian GAAP to IFRS.

After the adoption of IFRS, the quality of earnings reported by Malaysian companies is relatively higher than before the adoption (Wan Ismail, Kamarrudin, van Zijl \& Dunstan, 2012). Using 4,010 observations over total six years, the results show that adoption of IFRS increases earnings quality. In particular, the absolute value of abnormal accruals is lower and the value-relevance of firm's earnings is higher after the adoption of IFRS. Evans, Houston, Peters and Pratt (2012) asked experienced financial officers from the U.S, Europe and Asia to 
participate in a web-based case exercise to compare allowable earnings management under GAAP and IFRS. They find that financial officers under IFRS receive more allowable reporting discretion than those under GAAP but there is no evidence that IFRS leads to a greater likelihood of earnings management relative to GAAP. Thus regulatory environments allowing high levels of reporting discretion do not lead to more earning management but allow management to substitute accounting earning management for real earnings management (Evans et al. 2012). Contrary to the above studies, Jeanjean and Stolowy (2008) who analyse the effect of the mandatory introduction of IFRS on earnings management in three first time adopters: France, Australia and the UK, find that the pervasiveness of earnings management did not decline after the introduction of IFRS, in fact in France it increased. They explain that management incentives and national institutional factors play an important role in framing financial reporting characteristics, probably more important than accounting standards alone.

\section{Hypothesis development}

We draw on the relationship between cultural dimensions such as power distance, uncertainty avoidance, individualism and masculinity and earning management to hypothesize the relation between secrecy and earnings quality.

The relationships between cultural values and earnings management is a significant topic in accounting literature but there is mixed evidence on the direction of the relationships. Han, Kang, Slater and Yoo (2010) observe that earnings management decreases (increases) with uncertainty avoidance in weak (strong) investor protection countries. Furthermore, there is evidence that there is more earning management in individualistic societies than in collective societies; individualism has greater influence on earnings management in strong 
investor protection regimes. These results find support in Guan and Pourjalali (2010) examine the possible impact of cross-country differences in culture on earnings management in 27 countries. The results indicate that the higher is uncertainty avoidance the lower is earnings management. However, the higher the value of individualism, the higher the magnitude of earnings management.

The above results are in contrast to the findings of Callen et al. (2011) who use crosscountry data to research the impact of culture and religion on earnings management. They find that earnings management is negatively related to individualism and positively related to uncertainty avoidance. These results find support in the studies by Nabar and Boonlert-UThai (2007) and Desender et al. (2011). Nabar and Boonlert-U-Thai (2007) find that earnings management is relatively high in countries with high uncertainty avoidance scores and relatively low in countries where English is the primary language. They conclude that culture is an important determinant of accounting choice and should be considered by standards setters enacting and enforcing international financial reporting rules. Desender et al. (2011) who hypothesize that countries with higher levels of individualism or egalitarianism have lower levels of earnings quality and find that various cultural groups have significant differences in earnings management. In particular, they find that individualism is negatively related with earnings management whereas egalitarianism correlates positively with lower corruption and greater transparency in financial markets.

Hope, Kang, Thomas and Yoo (2008) use a large cross country sample to examine the relationship between culture and auditor choice as indirect evidence on the relationship between culture and earnings quality. Hope et al (2008) find that there is a negative relationship between secrecy and quality of auditor choice but that the relationship is 
mitigated by the degree of international orientation of firms. The measure of secrecy used is a composite of the Hofstede (1980) dimensions, viz, secrecy is the sum of uncertainty avoidance and power distance scores less the score for individualism.

In common with the above studies, our study also focusses on secrecy and earnings quality but we measure secrecy by the Financial Secrecy Index of the National Tax Justice Network (2015). A broad view of the related empirical literature summarised above leads us to the following hypothesis:

Hypothesis 1.There is negative relationship between secrecy and earnings quality.

There have been a large number of studies that have examined the relation between IFRS adoption and earnings quality The studies include Barth et al. (2008), Soderstrom and Sun (2008), Gebhardt and Novotny-Farkas (2011), Chua et al. (2012) and Houqe et al. (2012). The literature review paper ICAEW (2015) concludes that the results of these and other studies vary to the extent that no conclusions can be drawn and that this variation in results is likely due to the "different samples and methodologies" (p.52) used in the studies. Similarly, the recent review study by De George, Li and Shivakumar (2016) concludes that the evidence from both country specific and cross country studies on the impact of mandatory adoption of IFRS on earnings quality is mixed. This uncertain state of the literature provides support for further research on the impact of adoption of IFRS such as undertaken in the present study. 
Although the results are mixed we, nevertheless, posit the following hypothesis:

Hypothesis 2. There is a positive relationship between IFRS adoption and earnings quality.

Some researchers argue that accounting does not operate in a vacuum: it is 'a product of its environment' (Armstrong et al. 2010). One important factor in the environment is culture and thus differences in culture can have a significant impact on financial disclosures. Therefore, this study argues that culture and mandatory IFRS adoption will have a joint effect on earning quality. For example, Doupnik and Riccio (2006) suggest that national cultural values can affect accountants' interpretation of probability expressions used in IFRS, and as a result, differences in cultural values across countries could lead to differences in recognition and disclosure decisions based on those interpretations. They obtain strong support for that. Through culture's influence on the accounting value of secrecy, culture affects the interpretation of verbal probability expressions used to establish the threshold for when disclosures should be made

Many researchers question the success of IFRS when there are several factors such as investor protection, securities regulation and culture affecting financial report preparers' incentives. Narktabtee and Patpanichchot (2011) examine the impact of country level and firm- level factors on the effectiveness of IFRS adoption by evaluating the change in value relevance of earnings and book value of equity during pre and post IFRS adoption. The result indicates that the adoption of IFRS improves value relevance in all cases except the case where investor protection is weak and firms have characteristics which allow managers to use managerial discretion. Therefore, there is evidence that country level and firm level have 
effect on the effectiveness of IFRS adoption. In this study, we argue that the effect of IFRS adoption on earnings quality depends on culture, as indicated by the secrecy level.

In view of the prior studies, our expectation is that a high level of secrecy discourages managers to share information with outside investors and creates information asymmetry. However, the adoption of high-quality standards should mitigate the negative effect of secrecy and therefore we develop the following hypothesis to test the joint effect of secrecy and IFRS adoption on earnings quality:

Hypothesis 3. Following IFRS adoption, earnings quality improves more the higher the level of secrecy in a country.

\section{Research design}

\subsection{Macro- level variables}

The Financial Secrecy Index (FSI) from the U.S. Tax Justice Network (2015) was introduced in an effort to understand global financial secrecy, corruption and illicit financial flows. The FSI is a comprehensive indicator of secrecy which comprises of both qualitative and quantitative measurements. The qualitative side of the FSI considers laws, regulations, cooperation with information exchange process, and other verifiable data sources (Tax Justice Network, 2015). Quantitatively, a global score of secrecy is computed based on each jurisdiction's share of offshore financial services. Countries are then classified as either a High Secrecy country or a Low Secrecy country based on their Secrecy Score. Countries with a Secrecy Score above 50 are said to be in a High Secrecy jurisdiction. And those with scores equal to or below 50 are categorized as a Low Secrecy jurisdiction. 
Many prior studies, such as Francis and Wang, 2008 and Leuz et al, 2003, have applied the anti- director rights index developed by La Porta et al. (1998) as a measure of investor protection. However, this index has been criticized for its ad hoc nature and for several conceptual ambiguities and mistakes in coding (Djankov, La Porta, Lopez-deSilances, and Shleifer, 2008). We therefore use the World Economic Forum (2015) data to provide five alternative measures of the country variable degree of investor protection. These are judicial independence, protection of minority shareholders' interests, regulation of securities exchange, irregular payments and bribes, and financing through the local equity market. Judicial independence is the idea that the judiciary needs to be kept separate from and independent of influence from other branches of government, citizens, or firms (World Economic Forum, 2015). The measure of judicial independence ranges from 1 to 7 , where 1 signifies heavily influenced and 7 signifies entirely independent. Strong judicial independence is an indicator for competitive advantage of a country. However, it does not guarantee that a country with strong judicial independence has effective enforcement of accounting regulation. In prior research, Houqe et al. (2012) use judicial independence to examine the investor protection environment. The legal rules create features of a country's structure of corporate ownership and finance (La Porta, Lopez- de-Silanes, Shleifer and Vishny, 1998). If a country with low judicial independence chose to have only bank financing of firms then the country will adjust its laws accordingly to give better protection to banks potentially at the expense of shareholders' interest (La Porta et al, 1998). In this case, the disclosure requirements could be limited leading to lower quality of accounting information. 
The second measure of investor protection is protection of minority shareholders' interests. In particular, it measures the extent to which there is protection for the rights of outside investors against errant and manipulative management of inside investors through corporate law. More protection of minority shareholders' interest eliminates the opportunistic behaviour of managers and owners; therefore, the quality of accounting disclosure will be improved. Prior research shows that countries with strong protection of minority shareholders' rights limits insiders' ability to acquire private benefits and reduces incentives to corrupt accounting practices (Leuz et al. 2003; Francis and Wang, 2008). Boonlert-U-Thai, Meek and Nabar (2006) find that earnings are less smooth in countries whose institutional characteristics are strong. Moreover, Francis, Khurana and Pereira (2003) document that financial disclosure are more transparent and national accounting standards require timelier reporting in a country with stronger investor protection. They also find evidence that higher quality standards and the enforcement of these standards is more likely exist in countries with strong investor protection. Therefore, strong protection of minority shareholders' interests is associated with high quality accounting information (Hung, 2001).

Regulation of securities exchange is the third indicator of investor protection and measures the ability of investors to assess the regulation and supervision of securities exchanges in countries (World Economic Forum, 2015). Hail and Leuz (2006) show that the effectiveness of securities regulation has negative effects on the cost of equity capital. Effective security regulation requires firms to have certain disclosure levels and thus information asymmetries are limited (Hail and Leuz, 2006). Securities regulation can be measured by the disclosure requirement index and public enforcement (La Porta, Lopez- deSilanes and Shleifer, 2006). Specifically, disclosure requirements reveal disclosure in the areas of prospectus, compensation, shareholders, inside ownership, contracts irregular and 
transactions (La Porta et al, 2006). Public enforcement indicates the market supervisor power, rule- making power and investigative power (La Porta et al, 2006). In our research we use the measure of World Economic Forum. The index is scaled from 1 to 7 where 1 indicates that regulation of securities exchange is ineffective and 7 indicates that the regulation is effective.

Irregular payments and bribes indicates how common it is for firms in a country to make undocumented extra payments or bribes connected with (1) imports and exports, (2) annual tax payments, (3) public utilities, (4) awarding of public contracts and licenses, (5) obtaining favourable judicial decisions (World Economic Forum, 2015). The final macrolevel variable that is considered as an indicator of investor protection is financing through the local equity market which indicates the extent to which a company can raise money by issuing shares on the stock market; it is an indicator of the efficiency of the financial market. Other indicators include availability of financial services, affordability of financial services, ease of access to loans and venture capital availability. The development of financial markets creates opportunity for companies to raise funds but it also has certain requirements, restrictions and guidelines to maintain the integrity of the financial system. Francis et al. (2003) find that higher quality accounting and auditing are positively related with financial development in countries whose legal systems support protection of investors.

\subsection{Sample selection.}

Company financial data for the period 1998 to 2004 and 2006 to 2014 for the 16 European countries with mandatory adoption in 2005 was obtained from the Bloomberg Database. We excluded 2005 as that was the year of mandatory adoption of IFRS for the sample countries and we required two consistent successive years for the calculation of our measure of earnings quality. We deleted firm-year observations for companies that were early adopters 
and also observations with missing values on dependent and independent variables. In addition, following prior research (Jaggi and Low, 2011; Francis and Wang, 2008) we delete financial institutions such as banks and insurance companies (Standard Industrial Classification (SIC) 6000- 6999). We also exclude observations with any variables registering in the top or bottom $1 \%$ of the range of the variables in order to mitigate the effect of outliners. Finally, we drop observations with an absolute value of studentized residuals greater than 3 in the abnormal accruals analysis. As a result of this selection process our sample consists of 24,034 firm year observations from 16 countries for the period 1998 to 2004 and 2006 to 2014. The sample selection process is summarized in Table 1.

\section{[Insert Table 1 here]}

\subsection{Signed abnormal accruals analysis}

Larger unexpected abnormal accruals imply greater management earnings and lower earnings quality; thus, abnormal accruals are used as the measure of earning quality in financial reporting. Several studies have used signed abnormal earnings as the measure of earnings quality (Houqe et al. 2012; Francis and Wang, 2008). In this research we use signed abnormal accruals rather than absolute abnormal accruals for two reasons. Firstly, the use of managerial manipulation to increase reported earnings is the main focus of the research. In addition, there is evidence that signed abnormal accruals give a better measure of earnings quality than the unsigned value of abnormal accruals (Hribar and Nichols, 2007). 
Jones (1991) explains working capital accruals and depreciation as a function of sales growth and property, plant and equipment but her model only explains about $10 \%$ of the variation in accruals (Dechow, Ge and Schrand, 2010). Dechow, Sloan and Sweeney (1995) modify the Jones model to adjust for growth in credit sales, increasing the power of the model to yield a residual that is uncorrelated with expected revenue accruals and detecting revenue manipulation (Dechow et al. 2010). However, the modified model still contains the same limitations as the Jones model. In order to avoid that problem, Francis and Wang (2008) suggest applying a linear expectation model adapted from DeFond and Park (2001) that uses a firm's own prior year accruals in calculating the expectation benchmark. This model has several advantages. Firstly, the model limits cross-country differences in accounting principles by using a firm as its own control to identify abnormal accruals. Moreover, the model performs reliably in international settings (Francis and Wang, 2008). Thus, are measured as total accruals less predicted accruals, where:

Predicted accruals $=$

$\frac{\left\{\left[\text { Sales year } t \times\left(\frac{\text { current accruals in year } t-1)}{\text { sales in year } t-1}\right)\right]-\left[\text { gross PPE in year } t \times\left(\frac{\text { depreciation in year } t-1}{\text { gross PPE in year } t-1)}\right)\right]\right\}}{\text { total assets year } t-1}$

and Total accruals $=($ Earnings before extraordinary items operating cash flows $)$ / total assets in year $t-1$

We test our hypotheses using Model (2) below which expresses signed abnormal accruals as a linear function of financial secrecy, IFRS adoption and their interaction, subject to a set of firm-level controls and country level investor protection. 
$A b \_$Accruals $_{i t}=\beta_{0}+\beta_{1} S E C+\beta_{2} I F R S+\beta_{3} S E C * I F R S+\beta_{4} B I G \_4+\beta_{5} I N V+\beta_{6} L N \_S A L E S_{i t}$ $+\beta_{7} F_{-} L E V_{i t}+\beta_{8} S \_G W T H_{i t}+\beta_{9} \triangle P P E_{i t}+\beta_{10} C F O_{i t}+\beta_{11} L O S S_{i t}+$ fixed effects

where,

Ab_Accruals

SEC

IFRS

BIG_4

$I N V$

(i) JUD

(ii) $M I N$

(iii) RSE

(iv) IIPB

(v) FTEM

LN_SALES

F_LEV

S_GWTH

$\triangle P P E$
$=$ signed abnormal accruals of firm $i$ in year $t$

= Financial Secrecy Index from Tax Justice Network (2015).

$=$ value of 1 from the second year of adoption and the value 0 in the years before adoption.

value of 1 if the auditor is a Big 4 auditor (Deloitte, Ernst Young, $=\mathrm{KPMG}$, and PWC) and 0 otherwise.

= investor protection - measured by the following five alternative variables

= judicial independence scores from World Economic Forum (2015)

$=$ protection of minority shareholders' interest scores from World Economic Forum (2015)

$=$ regulation of securities laws scores from World Economic Forum (2015)

= irregular payment and bribes scores from World Economic Forum (2015)

= financing through local equity market scores from World Economic Forum (2015)

$=$ natural logarithm of total sales of firm $\mathrm{i}$ in year $\mathrm{t}$.

$=$ total long term debt divided by shareholders' equity of firm i in year $\mathrm{t}$.

$=$ sales growth rate, defined as the sales in year $\mathrm{t}$ minus sales in year $t-1$ and divided by sales year $t-1$

growth rate of gross PPE, defined as the gross PPE in year $t$ minus the gross PPE in year $t-1$ and scaled by the gross PPE in year $t-1$

$=$ operating cash flows for firm $i$ in year $t$ scaled by total assets. 
$=$ takes the value of 1 if firm $i$ in year $t$ reports negative income before extraordinary items and 0 otherwise.

Fixed effects are

(i)Industry dummies $=\mathrm{a}$ vector of dummy variables indicating industry sector membership.

(ii)Year dummies $\quad=$ a vector of dummy variables indicating year.

The coefficients of primary interest are: $\beta_{1}, \beta_{2}$ and $\beta_{3}$. The coefficient $\beta_{1}$, captures the effect of secrecy on abnormal accruals of firms; the coefficient $\beta_{2}$ shows the impact of mandatory adoption of IFRS on signed abnormal accruals. The coefficient $\beta_{3}$ on the interaction term measures the joint effect of secrecy and IFRS adoption on accruals. If $\beta_{3}$ is negative and significant, there is evidence that IFRS adopters have higher earnings quality than non-IFRS adopters in a country with high level of secrecy.

The five variables acting as a country level control for investor protection are highly correlated and therefore we introduce the variables one at a time. The variables could be introduced in the form of a composite index but that would result in loss of precision.

Based on prior research we include a number of firm specific control variables (Houqe et al. 2012; Francis and Wang, 2008). Choice of auditor (BIG_4) is a common proxy for the quality of the audit undertaken and would be expected to have a negative relationship with abnormal accruals. Company size $\left(L N \_S A L E S\right)$ is controlled for because it has a negative relationship with accruals (Klein, 2002). Leverage $\left(F_{-} L E V\right)$ is positively related to accruals and thus we control for leverage (Klein, 2002). Following the prior studies (Francis, LaFond, Olsson and Schipper, 2005; Houqe et al. 2012), we also include growth in sales $\left(S \_G W T H\right)$ and property, plant and equipment $(\triangle P P E)$ to the model. These variables may 
affect yearly accruals if the association between accruals and the drivers of accruals (sales and gross PPE) is nonlinear (Francis and Wang, 2008). Dechow and Dichev (2002) show accruals as a function of current, past and future cash flows and find that smaller firms have more volatile cash flows, accruals and earnings and are likely to report a loss.

\section{Empirical results}

\subsection{Descriptive statistics}

\section{[Insert Table 2 here]}

Table 2 shows the number of firms and the number of firm- year observations for each country and descriptive statistics for the country level variables. Most of the firm year observations are for UK with 8,248 observations (34.3\%) while $16.1 \%$ of the total sample comes from France and $12.7 \%$ come from Germany and $6.5 \%$ from the Netherlands. Ireland and Portugal have the lowest representation with $1.2 \%$. In a robustness test we exclude the larger countries.

The level of secrecy (SEC) has a wide range from 31 for Denmark and Finland to 73 for Switzerland. For judicial independence (JUD), Spain has the lowest score (3.2) while Finland has the highest score of 6.6. The higher is JUD, the stronger the independence of the judiciary from other branches of government, citizens or firms. The value of the protection of minority shareholders (MIN) ranges from 3.3 for Italy to 6.2 for Finland. Finland has the highest score of 6.1 for regulation of securities exchange (RSE) while Greece has the lowest score of 3.7. The score for irregular payments and bribes (IIPB) ranges from 3.8 for Greece and Italy to 6.6 for Finland. Finally, Norway has the highest score of 5.0 for financing 
through local equity market (FTEM) while Spain has the lowest at 2.9. It is evident from Table 2, that Finland has the strongest investor protection among the countries in the sample.

\section{[Insert Table 3 here]}

Descriptive statistics for firm level variables are reported in Table 3. The mean of Ab_Accruals is -0.0125 . The minimum value of Ab_Accruals is -0.0680 while the maximum value is 0.0466 . For IFRS, $62 \%$ of the observations are from the post adoption period. Of the total observations, $39 \%$ reflect a net loss and $84 \%$ are for $B I G \_4$. LN_SALES, has a mean of 5.2585 and standard deviation of 2.1101 . The mean value of financial leverage $\left(F \_L E V\right)$ is $47.24 \%$, the mean sales growth rate $\left(S \_G W T H\right)$ is $14.10 \%$, mean value of CFO is 0.0725 , and the mean growth rate of gross PPE $(\triangle P P E)$ is $13.98 \%$.

\section{[Insert Table 4 here]}

Table 4, shows that $S E C$ is positively related to $A b \_$Accruals while IFRS is negatively related to Ab_Accruals. The higher the level of Ab_Accruals, the higher the level of earnings management and therefore the reported Pearson correlations are consistent with our Hypotheses 1 and 2. There is a negative relationship between secrecy and earnings quality and positive relationship between IFRS and earnings quality. 


\subsection{Main results}

\subsubsection{Secrecy and IFRS}

\section{[Insert Table 5 here]}

The main results of our analysis are presented in Table 5. Each measure of investor protection is tested once and thus we have five regressions. All estimations are significant with adjusted $\mathrm{R}^{2}$ greater than $18 \%$. The significance levels on the individual coefficients are reported as two- tailed p-values.

The coefficient on the secrecy variable is positive and significant $(\mathrm{p}<0.01)$ in all estimations of the model. The positive sign of the coefficient on secrecy indicates that abnormal accruals increase with secrecy. This result suggests that the secrecy level of a country has a negative effect on earnings quality and thus supports our Hypothesis 1.

The IFRS variable measures the effect of IFRS adoption on abnormal accruals. The coefficient on the IFRS variable is negative in all models but just weakly significant $(\mathrm{p}<0.1)$ in only the MIN and IIPB models. The results are thus weakly consistent with our Hypothesis 2.

The interaction of secrecy with the IFRS variable measures the joint effect of secrecy and IFRS. The interaction term has a negative coefficient and is significant $(\mathrm{p}<0.01)$ in all models. Thus the total coefficient on IFRS, $\left(\beta_{2}+\beta_{3} \mathrm{x}\right.$ SEC), becomes increasingly negative with higher secrecy. This indicates that the impact of mandatory adoption of IFRS on earnings quality is stronger the higher the level of secrecy in a country. Thus the results are 
consistent with our Hypothesis 3. This has the important economic implication that the magnitude of the benefits arising from introduction of improved accounting standards will depend on the extant institutional environment.

The coefficients on INV, LN_SALES and CFO are negative and significant in all estimations and the coefficients on $F_{-} L E V$ and $L O S S$ are positive and significant in all estimations. The impacts of the control variables INV, LN_SALES, F_LEV, CFO and LOSS thus conform to expectations. However, while BIG_4 is negative and moderately significant in the three estimations, INV = JUD, RSE and FTEM, it is not significant in the other two estimations. The impact of audit quality is thus weaker than expected. The control $S \_G W T H$ is weakly significant in all estimations but $\triangle P P E$ is not significant in any of the estimations and there is therefore only limited support for the possibility of the impact of sales and gross PPE on accruals being non-linear.

\subsection{Robustness tests}

\subsubsection{Alternative measure for earnings quality}

\section{[Insert Table 6 here]}

To check for the consistency of our results with the results reported in the prior literature on earnings quality, we re-estimated the model using the Jones (1991) metric for earnings management. Abbreviated results are reported in Table 6 and in respect of secrecy and the impact of IFRS are consistent with our main results reported in Table 5. However, under this metric the impact of audit quality appears to be much stronger. 


\subsubsection{Alternative measure for secrecy}

\section{[Insert Table 7 here]}

We examine the robustness of our results by using an alternative measure of secrecy, viz, the Political System score from the Democracy Ranking (2014). We choose this alternative on the basis that a high democracy ranking is likely to reflect a high level of transparency - the opposite of secrecy. For consistency with the definition of the secrecy variable in the regression tests, we define POL_SYS as the complement of the score reported in the Democracy Ranking. The variables SEC and POL_SYS thus measure the same dimension. However, they are only moderately correlated $(0.518, \mathrm{p}=0.051)$ and thus $P O L \_S Y S$ provides a suitable basis for a test of robustness. Abbreviated results are reported in Table 6 and show that the coefficient on POL_SYS is in each case positive and significant and the coefficients on the interaction term have the same sign and significance as reported in Table 5. Our primary results are thus robust to this variation in the choice of the measure of secrecy.

\subsubsection{Other institutional changes}

\subsubsection{Enforcement scores}

\section{[Insert Table 8 here]}

Our measure of investor protection varies across the countries in our sample but is constant over time for each country. Therefore our results are open to the possibility that the apparent impact of adoption of IFRS and secrecy may actually reflect (at least in part) other sources such as concurrent changes in enforcement and other institutional factors. This issue is 
highlighted in Christensen, Hail and Leuz (2013) with comment by Barth and Israeli (2013). Therefore, we further test the robustness of our results using the country level enforcement scores from the study by Brown, Preiato and Tarca (2014) which provides measures of the audit and accounting enforcement environments for 2002, 2005 and 2008 for each of 51 countries including the 16 European countries in our sample. The sample countries averaged similar enforcement scores for 2005 and 2008 but showed significant differences between the enforcement scores for 2002 and 2008 (mean of 10.1 vs 16.4 from a maximum score of 24). We therefore constructed the variable ENFORC, set equal to the scores for enforcement for 2002 and for 2008 for the pre and post IFRS adoption observations respectively, and then reestimated our model with ENFORC substituting for the variable INV. The abbreviated results are reported in Table 7 which shows a significant increase in adjusted $\mathrm{R}^{2}$ and while the variable ENFORC is significant the main results for secrecy and adoption of IFRS continue to hold.

\subsubsection{Pre and post IFRS adoption periods}

\section{[Insert Table 9 here]}

We re-estimated the model using only the observations for 2003-2004 (pre adoption of IFRS) and 2006-2007 (post adoption of IFRS). The results are reported in Table 9 and are consistent with our primary results reported in Table 5. This test provides additional assurance that the apparent impact of adoption of IFRS and secrecy is robust to controlling for changes in the institutional environment concurrent with adoption of IFRS. While we have conducted two robustness tests for changes concurrent with adoption of IFRS the tests 
are not exhaustive of changes over the sample period that may have impacted our results and this limitation therefore remains significant. ${ }^{1}$

\subsubsection{Excluding United Kingdom, France, Germany and the Netherlands}

\section{[Insert Table 10 here]}

To provide assurance that the primary results are not unduly driven by the observations from the four countries providing the largest numbers of observations in the sample, we reestimated the model with the sample formed by deleting the observations from those four countries. The results reported in Table 10 are consistent with our main results. We thus conclude that the observations for the UK, France, Germany and the Netherlands do not drive our results.

\subsubsection{High vs Low Secrecy}

\section{[Insert Table 11 here]}

To test the robustness of the scale used for the primary measure of secrecy we re-estimated the model with SEC assigned the value 1 for a high secrecy country and the value 0 for a low secrecy country. The results reported in Table 10 are consistent with our main results reported in Table 5.

\footnotetext{
${ }^{1}$ Filip and Raffournier (2014) report a significant decrease in income manipulations by listed European companies during the 2008-2009 financial crisis and thus provide another example of the myriad of changes that took place during our sample period and with possible impact on the apparent impact of adoption of IFRS.
} 


\section{Conclusion}

We hypothesize that culture influences financial reporting quality. Specifically, we test whether the extent of secrecy in a country negatively impacts on earnings quality. Using 24,034 firm year observations from 16 European countries, our evidence indicates that there is a negative relation between secrecy and earnings quality. Our study adds to the discussion of the effects of mandatory IFRS adoption across countries. We find support for mandatory adoption of IFRS having a positive on earnings quality and that the impact is stronger the higher the level of secrecy in a country.

We conduct a number of robustness tests and find that in each case our findings are robust. Nevertheless, the results are subject to certain limitations which reflect the aggregated cross-country research design. Firstly, our analyses may not have considered the impact of changes in other important macro level variables on earnings quality. Secondly, the sample includes only observations from highly developed European countries and thus while the results may be indicative of secrecy and the impact of IFRS for those countries, the variety in the sample is inevitably limited and therefore the results may have limited generalizability. Finally, our study is based on only a relatively short period following adoption of IFRS and the longer term impact may also be different. 


\section{References}

Armstrong, C. S., Barth, M. E. and Riedl, E. J. (2010). Market reaction to the adoption of IFRS in Europe. The Accounting Review, 85(1): 31-61.

Asiyaban, S. and Abdoli, M. (2012). The effect of cultural values on accounting values. Culture, 4(4).

Ball, R. (2006). International Financial Reporting Standards (IFRS): Pros and Cons for Investors. Accounting and Business Research, 36(Sup.1): 5-27.

Ball, R., Robin, A. and Wu, J. S. (2003). Incentives versus Standards: Properties of Accounting Income in Four East-Asian Countries. Journal of Accounting and Economics, 36(1-3): 235-270.

Ball, R., Kothari, S. P. and Robin, A. (2000). The effect of international institutional factors on properties on accounting earnings. Journal of Accounting and Economics, 29(1): 151.

Barth, M., Landsman, W. and Lang, M. (2008). International Accounting Standards and Accounting Quality. Journal of Accounting Research, 46(3): 467-498.

Barth, M. and Israeli, D. (2013). Disentangling mandatory IFRS reporting and changes ion environment. Journal of Accounting and Economics, 56: 178-188.

Boonlert- U- Thai, K., Meek, G. and Nabar, S. (2006). Earnings attributes and investorprotection: International evidence. The International Journal of Accounting, 41(4): 327-357.

Callao, S., Jarne, J. and Lainez, J., (2007). Adoption of IFRS in Spain: Effect on the comparability and relevance of financial reporting. Journal of International Accounting, Auditing and Taxation, 16(2): 148-178. 
Callen, J. L., Morel, M. and Richardson, G. (2011). Do culture and religion mitigate earnings management? Evidence from a cross-country analysis. International Journal of Disclosure and Governance, 8(2): 103-121.

Christensen, H., Hail, L. and Leuz, C. (2013). Mandatory IFRS reporting and changes in environment. Journal of Accounting and Economics, 56: 147-177.

Chua, Y., Cheong, C. and Gould, G., (2012). The impact of mandatory IFRS adoption on accounting quality: Evidence from Australia. Journal of International Accounting Research, 11(1): 119- 146.

Daske, H., Hail, L., Leuz, C. and Verdi, A. (2008). Mandatory IFRS Reporting around the World: Early Evidence on the Economic Consequences. Journal of Accounting Research, 46(5): 1085-1142.

Dechow, P. and Dichev, I. (2002). The quality of accruals and earnings: The role of accrual estimation errors. The Accounting Review, 77(1): 35-59.

Dechow, P., Ge, W. and Schrand, C. (2010). Understanding earnings quality: A review of the proxies, their determinants and their consequences. Journal of Accounting and Economics, 50 (2-3): 344-401.

Dechow, P., Sloan, R. and Sweeney, A. (1995). Detecting earnings management. The Accounting Review, 70(2): 193- 225.

DeFond, M. and Park. C. (2001). The reversal of abnormal accruals and the market valuation of earnings surprises. The Accounting Review, 76 (3): 375-404.

De George, E.T., Li, X. and Shivakumar, L. (2016). A review of the IFRS-adoption literature. Review of accounting Studies (forthcoming).

Desender, K., Castro, C. and Leon, S. (2011). Earnings management and cultural values. American Journal of Economics and Sociology, 70(3): 639- 670. 
Deloitte. (2016). Use of IFRS by jurisdiction. Retrieved from http://www.iasplus.com /Plone/en/resources/use-of-ifrs

Djankov, S., La Porta, R., Lopez-de-Silanes, F. and Shleifer, A. (2008). The law and economics of self-dealing. Journal of financial economics, 88(3): 430-465.

Doupnik, T., \& Perera, H. (2009). International Accounting, 2e. McGraw-Hill International.

Doupnik, T. and Riccio, E. (2006). The influence of conservatism and secrecy on the interpretation of verbal probability expressions in the Anglo and Latin cultural areas. The International Journal of Accounting, 41(3): 237-261.

Evans, M., Houston, R., Peters, M. and Pratt, J. (2012). Earnings management under U.S GAAP and IFRS. Working Paper. Retrieved from http://www.carlsonschool.umn.edu/accounting/midwest-summer-research-conference2012/schedule/documents/MarkEvansPaper.pdf

Feleaga, L., Dragomir, V. and Feleaga, N. (2010). National accounting culture and empirical evidence on the application of conservatism. Economic computation and economic cybernetics studies and research, 44(3): 43-60.

Filip, A. and Raffournier, B. (2014). Financial Crisis and Earnings Management: The European Experience. The International Journal of Accounting, 49: 455-478.

Francis, J., Khurana, I. and Pereira, R. (2003). The role of accounting and auditing in corporate governance and the development of financial markets around the world. Asia- Pacific Journal of Accounting and Economics, 10(1): 1- 30.

Francis, J., LaFond, R., Olsson, P. \& Schipper, K. (2005). The market pricing of accruals quality. Journal of Accounting and Economics, 39(2): 295- 327.

Francis, J., Wang, D. (2008). The Joint Effect of Investor Protection and Big 4 Audits on Earnings Quality around the World. Contemporary Accounting Research, 25(1): 157191. 
Gebhardt, G. and Novotny-Farkas, Z. (2011). Mandatory IFRS Adoption and Accounting Quality of European Banks. Journal of Business Finance and Accounting, 38(3-4): 289-333.

Gray, S. J. and Vint, H. M. (1995). The impact of culture on accounting disclosures: some international evidence. Asia-Pacific Journal of Accounting, 2(1): 33-43.

Gray, S. J. (1988). Towards a Theory of Cultural Influence on the Development of Accounting Systems Internationally. Abacus, 24(1): 1-15.

Guan, L.and Pourjalali, H. (2010). Effect of cultural environmental and accounting regulation on earning management: a multiple year- country analysis. Asia- Pacific Journal of Accounting \& Economics, 17(2): 99-127.

Hail, L. and Leuz, C. (2006). International differences in the cost of equity capital: Do legal institutions and securities regulation matter? Journal of Accounting Research, 44(3): $485-531$.

Han, S., Kang, T., Salter, S. and Yoo, Y. (2010). A cross-country study on the effects of national culture on earnings management. Journal of International Business Studies, 4l(1): 123-141.

Hofstede, G. (1980). Culture and organizations. International Studies of Management \& Organization, 10(4): 15-41.

Hope, O., Kang, T., Thomas, W. and Yoo, Y. (2008). Culture and auditor choice: A test of the secrecy hypothesis. Journal of Accounting and Public Policy, 27(5): 357-373.

Horton, J. and Serafeim, G. (2010). Market reaction to and valuation of IFRS reconciliation adjustments: first evidence from the UK. Review of Accounting Studies, 15(4): 725751. 
Houqe, M. N., van Zijl, T., Dunstan, K. and Karim, W. (2012). The effect of IFRS adoption and investor protection on earnings quality around the world. The International journal of Accounting, 47(3): 333-358.

Hribar, P. and Nichols, D. (2007). The use of unsigned earnings quality measures in tests of earnings management. Journal of Accounting Research, 41(3): 235-72.

Hung, M. (2000). Accounting standards and value relevance of financial statement: An international analysis. Journal of Accounting and Economics, 30(3): 401-420.

IASB (2012). International Accounting Standard Board. Available at www.ifrs.org

ICAEW (2015). The effects of mandatory IFRS adoption in the EU: A review of empirical research. Information for Better Markets, Institute of Chartered Accountants in England and Wales.

Jaggi, B. and Low, P. (2000). Impact of Culture, Market Forces and Legal System on Financial Disclosures. The International Journal of Accounting, 35 (4): 495-519.

Jeanjean, T. and Stolowy, H. (2008). Do accounting standards matter? An exploratory analysis of earnings management before and after IFRS adoption. Journal of Accounting and Public Policy, 27(6): 480-494.

Jeter, D. and Shivakumar, L., (1999). Cross- sectional estimation of abnormal accruals using quarterly and annual data: effectiveness in detecting event- specific earnings management. Accounting and Business Research, 29 (4): 299-319.

Jones, J. (1991). Earnings management during import relief investigation. Journal of Accounting Research, 29(2): 193-228.

Kang, T., Lee, L., Jeffrey NG, T. and Tay, J. (2004). The impact of culture on accounting choices: Can cultural conservatism explain accounting conservatism? Research Collection School of Accountancy (Open Acess). Paper 275. 
Klein, A. (2002). Audit committee, board of director characteristics, and earnings management. Journal of accounting and economics, 33(3): 375-400.

La Porta, R., Lopez-de-Silanes, F., and Shleifer, A. 1998. Law and Finance. Journal of Political Economy, 106 (6): 1113-1154..

La Porta, R., Lopez- de- Silanes, F.and Shleifer, A. (2006). What works in securities laws? Journal of Finance, 61(1): 1-32.

Leuz. C., Nanda, D. and Wyscocki, P. D. (2003). Earnings management and investor protection: An international comparison. Journal of Financial Economics, 69(3): 505527.

Liu, C., Yao, L., Hu, N. and Liu, L. (2011). The impact of IFRS on accounting quality in a regulated market: An empirical study of China. Journal of Accounting, Auditing \& Finance, 26(4): 659-676.

Nabar, S. and Boonlert-U-Thai, K. (2007). Earnings management, investor protection and national culture. Journal of International Accounting Research, 6(2): 35-54.

Narkatabtee, K, and Patpanichchot, S. (2011). The impact of country- level and firm- level factors on the effectiveness of IFRS adoption: The case of European Union. International business and Economics Research Journal, 10(10): 79-92.

National Tax Justice Network. (2011). Financial Secrecy Index. Available at http://www.financialsecrecyindex.com/

Salter, S. B. and Niswander, F. (1995). Cultural influence on the development of accounting systems internationally: A test of Gray's [1988] theory. Journal of International Business Studies, 379-397.

Richardson, G. (2008). The relationship between culture and tax evasion across countries: Additional evidence and extensions. Journal of International Accounting, Auditing and Taxation, 17(2): 67-78. 
Soderstrom, N. and Sun, K. (2007). IFRS adoption and accounting quality: A review. European Accounting Review, 16 (4): 675-702.

Sudarwan, M. and Fogarty, T. (1996). Culture and accounting in Indonesia: An empirical examination. The International Journal of Accounting, 31(4): 463-481.

Tax Justice Network, (2012). Financial Secrecy Index.

Available at http://www.financialsecrecyindex.com/

Teets, W. (2002). Quality of Earnings: An Introduction to the Issues in Accounting Education Special Issue, Issues in Accounting Education, 17 (4): 355-360.

Tendeloo, B. and Vanstraelen, A. (2005). Earnings management under German GAAP versus IFRS. European Accounting review, 14 (1): 155-180.

Tsakumis, G.T., Curatola, A.P. and Porcano, T.M. (2007). The Relation between National Cultural Dimensions and Tax Evasion. Journal of International Accounting, Auditing and Taxation, 16(2): 131-147.

Wan Ismail, W., Kamarudin, K., van Zijl, T. and Dunstan, K. (2012). Earnings Quality and the Adoption of IFRS-Based Accounting Standards: Evidence from an Emerging Market, Asian Review of Accounting, 21 (1): 53-73.

World Economic Forum. (2015). The global competitiveness report 2012- 2013. Retrieved from http://www.weforum.org/issues/global-competitiveness 
Table 1

Sample selection process

No. of observations (excluding early adopters) with no missing values on dependent and independent variables (1998-2004) - (2006-2014)

less observations with any variables registering in the top or bottom $1 \%$

less observations with $\mid$ Studentized residuals $\mid>3$ 
Table 2

Number of firm-years and Descriptive statistics for macro-level variables

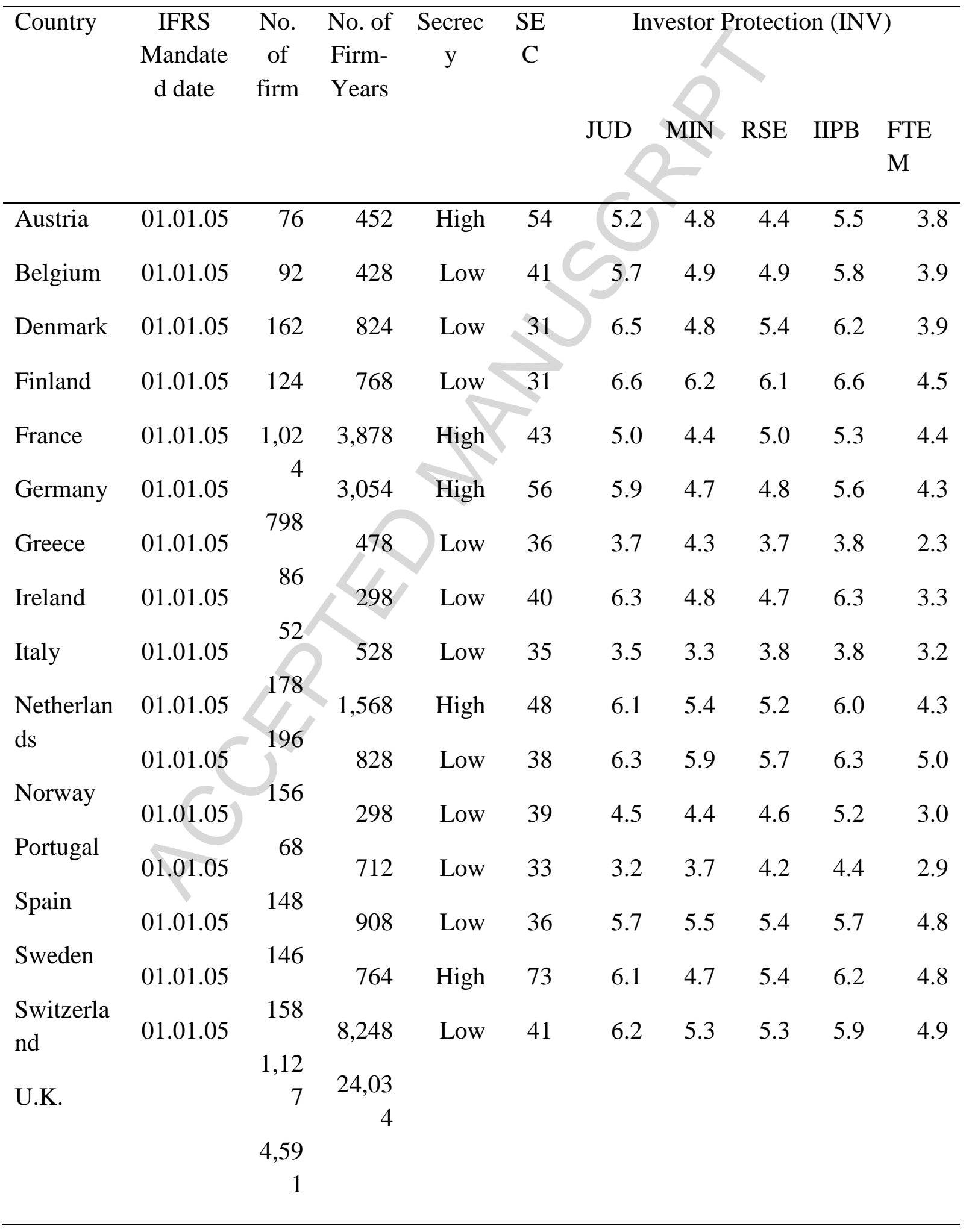

SEC is the Financial Secrecy Index from Tax Justice Network (2015). Investor Protection $(I N V)$ is investor protection as indicated by five different measures (1) JUD is the judicial 
independence scores from World Economic Forum (2015), (2) MIN is the protection of minority shareholders' interest scores from World Economic Forum (2015), (3) RSE is the regulation of securities laws scores from World Economic Forum (2015), (4) IIPB is the irregular payment and bribes scores from World Economic Forum (2015), and (5) FTEM is the financing through local equity market scores from World Economic Forum (2015). 
Table 3

Descriptive statistics for firm-level variables $(n=24,034)$

\begin{tabular}{lccccc}
\hline \multicolumn{1}{c}{ Variable } & Mean & Median & S.D & Minimum & Maximum \\
\hline Ab_Accruals & -0.0125 & -0.0110 & 0.1381 & -0.0680 & 0.0466 \\
IFRS & 0.6200 & 1 & 0.5421 & 0 & 1 \\
BIG_4 & 0.8412 & 1 & 0.4228 & 0 & 1 \\
LN_SALES & 5.2585 & 5.2675 & 2.1101 & 3.9875 & 7.8287 \\
F_LEV & 0.4724 & 0.4850 & 0.2368 & 0.1025 & 0.6486 \\
S_GWTH & 0.1410 & 0.0670 & 0.3895 & -0.0650 & 0.3829 \\
SPPE & 0.1398 & 0.0891 & 0.3498 & -0.0167 & 0.2478 \\
CFO & 0.0725 & 0.0965 & 0.1724 & 0.0014 & 0.1879 \\
LOSS & 0.3890 & 1 & 0.5587 & 0 & 1 \\
\hline
\end{tabular}

$A b \_$Accruals is the signed abnormal accruals of firm $i$ in year $t$ under DeFond and Park (2001) model (Francis and Wang 2008 and Houqe et al., 2012). IFRS takes the value of 1 from the second year of adoption and the value 0 in the years before adoption. BIG_4 takes the value of 1 if the auditor is a Big 4 auditor (Deloitte, Ernst Young, KPMG, and PWC) and 0, otherwise. $L N \_S A L E S$ is natural logarithm of total sales of firm $i$ in year $t . F \_L E V$ is the end of year total long term debt divided by end of year shareholders' equity of firm $i$ in year t. $S \_G W T H$ is the sales growth rate, defined as the sales in current year minus sales in prior year and divided by sales in prior year for firm $i$ in year $t . \triangle \mathrm{PPE}$ is the growth rate of gross PPE, defined as the gross PPE in current year minus the gross PPE in prior year and divided by the gross PPE in prior year for firm $i$ in year $t$. CFO is the operating cash flows for firm $i$ in year $t$ scaled by total assets. LOSS takes the value of 1 if firm $i$ in year $t$ reports negative income before extraordinary items and 0 otherwise. 


\section{Table 4}

Pearson Correlation Matrix $(n=24,034)$

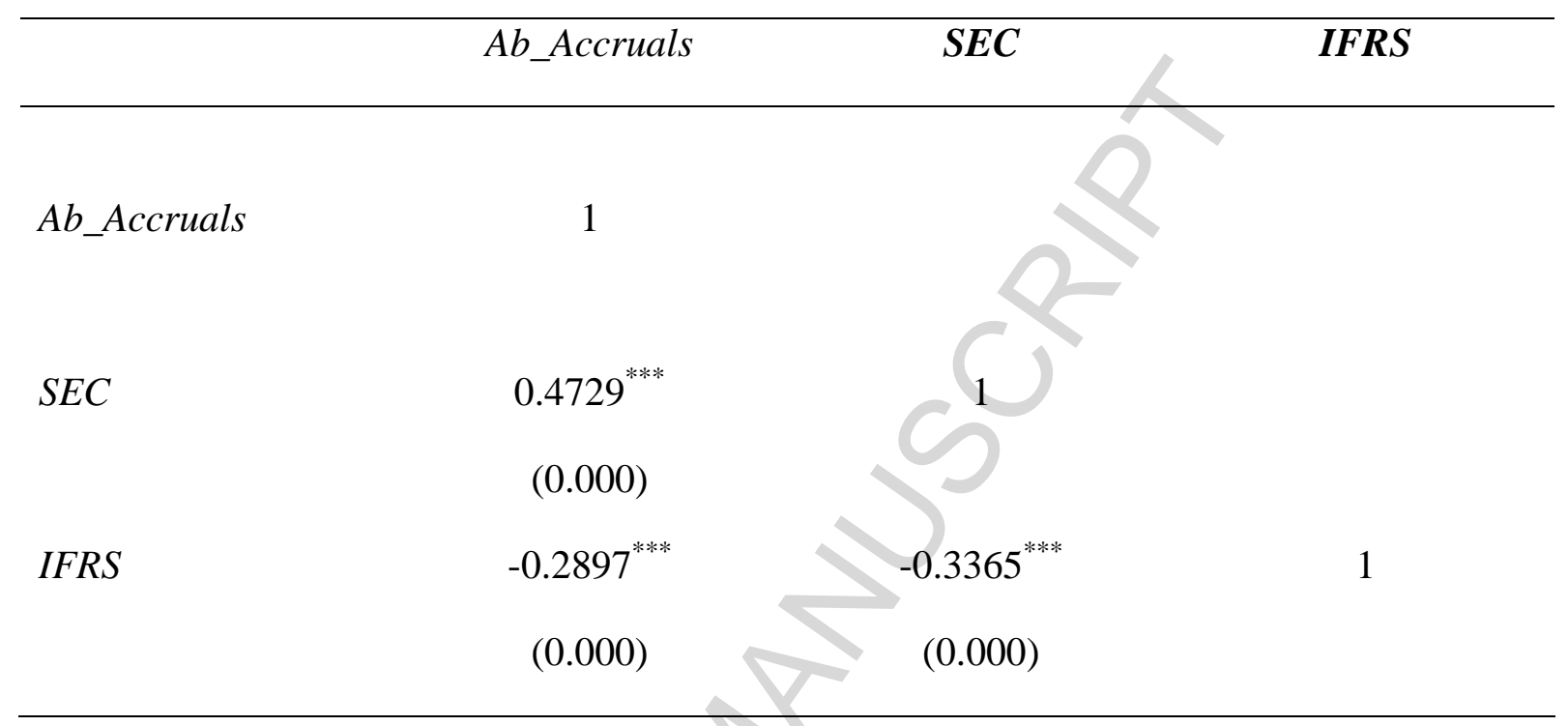

Note: Coefficient p-values are two-tail

Ab_Accruals is the signed abnormal accruals of firm $i$ in year $t$ under DeFond and Park (2001) model (Francis and Wang 2008 and Houqe et al., 2012). SEC is the Financial Secrecy Index from Tax Justice Network (2015). IFRS takes the value of 1 from the second year of adoption and the value 0 in the years before adoption. 


\section{Table 5}

\section{Main Results}

$A b \_$Accruals ${ }_{i t}=\beta_{0}+\beta_{1} S E C+\beta_{2} I F R S+\beta_{3} S E C * I F R S+\beta_{4} B I G_{-} 4+\beta_{5} I N V+\beta_{6} L N \_S A L E S_{i t}$ $+\beta_{7} F_{-} L E V_{i t}+\beta_{8} S_{-} G W T H_{i t}+\beta_{9} \Delta P P E_{i t}+\beta_{10} C F O_{i t}+\beta_{11} L O S S_{i t}+$ fixed effects

\begin{tabular}{|c|c|c|c|c|c|}
\hline \multirow[t]{3}{*}{$\begin{array}{l}\text { Independent } \\
\text { variables }\end{array}$} & $\mathrm{INV}=\mathrm{JUD}$ & $\mathrm{INV}=\mathrm{MIN}$ & $\mathrm{INV}=\mathrm{RSE}$ & $\mathrm{INV}=\mathrm{IIPB}$ & $\begin{array}{l}\text { INV = } \\
\text { FTEM }\end{array}$ \\
\hline & Estimate & Estimate & Estimate & Estimate & Estimate \\
\hline & (p-value) & (p-value) & (p-value) & (p-value) & (p-value) \\
\hline \multirow[t]{2}{*}{ Intercept } & $0.0045^{* * *}$ & $0.0047^{* * *}$ & $0.0046^{* * *}$ & $0.0049^{* * * *}$ & $0.0047^{\text {**** }}$ \\
\hline & $(0.000)$ & $(0.001)$ & $(0.000)$ & $(0.001)$ & (0.006) \\
\hline \multirow[t]{2}{*}{$S E C$} & $0.0014^{* * *}$ & $0.0012^{*}$ & $0.0013^{* * *}$ & $0.0014^{* * *}$ & $0.0014^{* * * *}$ \\
\hline & $(0.000)$ & $(0.000)$ & $(0.001)$ & $(0.001)$ & $(0.000)$ \\
\hline \multirow[t]{2}{*}{ IFRS } & -0.0000 & $.0001^{*}$ & -0.0000 & $-0.0001^{*}$ & -0.0001 \\
\hline & $(0.287)$ & .090) & $(0.181)$ & $(0.051)$ & $(0.227)$ \\
\hline \multirow[t]{2}{*}{$S E C * I F R S$} & -0.0015 & $-0.0014^{* * *}$ & $-0.0014^{* * *}$ & $-0.0016^{* * *}$ & $-0.0015^{* * *}$ \\
\hline & $(0.000)$ & $(0.000)$ & $(0.000)$ & $(0.000)$ & $(0.000)$ \\
\hline \multirow[t]{2}{*}{$B I G_{-} 4$} & $0.0040^{*}$ & 0.0020 & $-0.0102^{* *}$ & $-0.0051^{*}$ & -0.0000 \\
\hline & $(0.065)$ & $(0.254)$ & $(0.034)$ & $(0.086)$ & $(0.426)$ \\
\hline \multirow[t]{2}{*}{$I N V$} & $-0.0084^{* * *}$ & $-0.0081^{* * *}$ & $-0.0082^{* * *}$ & $-0.0084^{* * *}$ & $-0.0086^{* * *}$ \\
\hline & $(0.000)$ & $(0.000)$ & $(0.000)$ & $(0.000)$ & $(0.000)$ \\
\hline \multirow[t]{2}{*}{$L N \_S A L E S$} & $-0.0094^{* *}$ & $-0.0092^{*}$ & $-0.0088^{*}$ & $-0.0092^{* *}$ & $-0.0092^{* *}$ \\
\hline & $(0.050)$ & $(0.061)$ & $(0.071)$ & $(0.048)$ & $(0.034)$ \\
\hline \multirow[t]{2}{*}{$F_{-} L E V$} & $0.0018^{* *}$ & $0.0016^{*}$ & $0.0012^{* *}$ & $0.0017^{* *}$ & $0.0018^{* *}$ \\
\hline & $(0.038)$ & $(0.051)$ & $(0.021)$ & $(0.041)$ & $(0.021)$ \\
\hline \multirow[t]{2}{*}{$S \_G W T H$} & $-0.0013^{*}$ & $-0.0014^{*}$ & $-0.0012^{* *}$ & $-0.0014^{*}$ & $-0.0013^{*}$ \\
\hline & $(0.080)$ & $(0.079)$ & $(0.031)$ & $(0.059)$ & $(0.056)$ \\
\hline$\triangle P P E$ & -0.0010 & -0.0011 & -0.0010 & -0.0010 & -0.0011 \\
\hline
\end{tabular}




\begin{tabular}{lccccc}
\hline & $(0.358)$ & $(0.415)$ & $(0.487)$ & $(0.374)$ & $(0.404)$ \\
CFO & $-0.0047^{* * *}$ & $-0.0046^{* * *}$ & $-0.0044^{* * *}$ & $-0.0042^{* * *}$ & $-0.0043^{* * *}$ \\
& $(0.000)$ & $(0.001)$ & $(0.001)$ & $(0.002)$ & $(0.001)$ \\
LOSS & $0.0012^{* *}$ & $0.0016^{*}$ & $0.0013^{* *}$ & $0.0016^{* *}$ & $0.0017^{* *}$ \\
& $(0.021)$ & $(0.051)$ & $(0.021)$ & $(0.021)$ & $(0.020)$ \\
Fixed & Yes & Yes & Yes & Yes & Yes \\
Adjusted & $18.36 \%$ & $19.21 \%$ & $18.11 \%$ & $19.26 \%$ & $18.29 \%$ \\
\multicolumn{1}{c}{$\mathrm{N}$} & 24,034 & 24,034 & 24,034 & 24,034 & 24,034 \\
\hline
\end{tabular}

Note: Coefficient p-values applied two-tail and based on asymptotic Z-statistic robust to heteroscedasticity and country clustering effects using the method in Rogers (1993).

$A b \_$Accruals is the signed abnormal accruals of firm $i$ in year $t$ under DeFond and Park (2001) model (Francis and Wang 2008 and Houqe et al., 2012). SEC is the Financial Secrecy Index from Tax Justice Network (2015). IFRS takes the value of 1 from the second year of adoption and the value 0 in the years before adoption. $B I G_{-} 4$ takes the value of 1 if the auditor is a Big 4 auditor (Deloitte, Ernst Young, KPMG, and PWC) and 0, otherwise. INV is investor protection as indicated by five different measures (1) JUD is the judicial independence scores from World Economic Forum (2015), (2) MIN is the protection of minority shareholders' interest scores from World Economic Forum (2015), (3) RSE is the regulation of securities laws scores from World Economic Forum (2015), (4) IIPB is the irregular payment and bribes scores from World Economic Forum (2015), and (5) FTEM is the financing through local equity market scores from World Economic Forum (2015). $L N \_S A L E S$ is natural logarithm of total sales of firm $i$ in year $t . F_{-} L E V$ is the end of year total long term debt divided by end of year shareholders' equity of firm $i$ in year $t$. S_GWTH is the sales growth rate, defined as the sales in current year minus sales in prior year and divided 
by sales in prior year for firm $i$ in year $t$. $\triangle \mathrm{PPE}$ is the growth rate of gross PPE, defined as the gross PPE in current year minus the gross PPE in prior year and divided by the gross PPE in prior year for firm $i$ in year $t$. CFO is the operating cash flows for firm $i$ in year $t$ scaled by total assets. LOSS takes the value of 1 if firm $i$ in year $t$ reports negative income before extraordinary items and 0 otherwise. Fixed effects are (i) Industry dummies, a vector of dummy variables indicating industry sector membership. (ii) Year dummies, a vector of dummy variables indicating Year. 


\section{Table 6}

\section{Alternative measure of earnings quality, Jones (1991)}

\begin{tabular}{|c|c|c|c|c|c|}
\hline \multirow[t]{2}{*}{$\begin{array}{l}\text { Independent } \\
\text { variables }\end{array}$} & $\mathrm{INV}=\mathrm{JUD}$ & $\mathrm{INV}=\mathrm{MIN}$ & INV = RSE & INV $=$ IIPB & $\begin{array}{l}\text { INV = } \\
\text { FTEM }\end{array}$ \\
\hline & $\begin{array}{l}\text { Estimate } \\
\text { (p-value) }\end{array}$ & $\begin{array}{l}\text { Estimate } \\
\text { (p-value) }\end{array}$ & $\begin{array}{l}\text { Estimate } \\
\text { (p-value) }\end{array}$ & $\begin{array}{l}\text { Estimate } \\
\text { (p-value) }\end{array}$ & $\begin{array}{l}\text { Estimate } \\
\text { (p-value) }\end{array}$ \\
\hline Intercept & $\begin{array}{c}0.0524^{* * * * *} \\
(0.000)\end{array}$ & 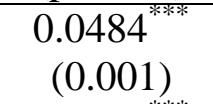 & $\begin{array}{c}0.0967^{* * *} \\
(0.000)\end{array}$ & $\begin{array}{c}0.0479^{* * * *} \\
(0.001)\end{array}$ & $\begin{array}{c}0.0698^{* * * * *} \\
(0.006)\end{array}$ \\
\hline SEC & $\begin{array}{c}0.0016^{* * * *} \\
(0.005)\end{array}$ & $\begin{array}{c}0.0019^{* * * *} \\
(0.003)\end{array}$ & $\begin{array}{c}0.0010^{* *} \\
(0.021)\end{array}$ & $\begin{array}{c}0.0022^{* * * *} \\
(0.000)\end{array}$ & $\begin{array}{c}0.0018^{* * *} \\
(0.003)\end{array}$ \\
\hline IFRS & $\begin{array}{c}-0.0010^{* * * *} \\
(0.002)\end{array}$ & $\begin{array}{c}-0.0012^{* * * *} \\
(0.001)\end{array}$ & $\begin{array}{r}-0.0001 \\
(0.348)\end{array}$ & $\begin{array}{c}-0.0006^{*} \\
(0.078)\end{array}$ & $\begin{array}{l}-0.0002 \\
(0.127)\end{array}$ \\
\hline$S E C * I F R S$ & $\begin{array}{c}-0.0017^{* * * *} \\
(0.002)\end{array}$ & $\begin{array}{c}-0.0021^{\text {**** }} \\
(0.000)\end{array}$ & $\begin{array}{c}-0.0011^{* *} \\
(0.042)\end{array}$ & $\begin{array}{c}-0.0018^{* * *} \\
(0.032)\end{array}$ & $\begin{array}{c}-0.0014^{* *} \\
(0.016)\end{array}$ \\
\hline$B I G \_4$ & $\begin{array}{c}-0.0174^{\text {***** }} \\
(0.000)\end{array}$ & $\begin{array}{c}-0.0138^{* * * *} \\
(0.001)\end{array}$ & $\begin{array}{c}-0.0167^{* * * *} \\
(0.001)\end{array}$ & $\begin{array}{c}-0.0138^{* * * *} \\
(0.000)\end{array}$ & $\begin{array}{c}-0.0158^{\text {**** }} \\
(0.000)\end{array}$ \\
\hline$I N V$ & $\begin{array}{c}-0.0082^{* * *} \\
(0.000)\end{array}$ & $\begin{array}{c}-0.0084^{* * * *} \\
(0.000)\end{array}$ & $\begin{array}{c}-0.0086^{\text {****}} \\
(0.001)\end{array}$ & $\begin{array}{c}-0.0094^{* * * *} \\
(0.000)\end{array}$ & $\begin{array}{c}-0.0088^{* * * *} \\
(0.000)\end{array}$ \\
\hline Controls & Yes & Yes & Yes & Yes & Yes \\
\hline Fixed effects & Yes & Yes & Yes & Yes & Yes \\
\hline Adjusted $\mathrm{R}^{2}$ & $27.14 \%$ & $29.32 \%$ & $21.28 \%$ & $28.28 \%$ & $26.24 \%$ \\
\hline $\mathrm{N}$ & 24,034 & 24,034 & 24,034 & 24,034 & 24,034 \\
\hline
\end{tabular}

Note: Coefficient p-values applied two-tail and based on asymptotic Z-statistic robust to heteroscedasticity and country clustering effects using the method in Rogers (1993).

$D A C C R$ is the discretionary accruals of firm $i$ in year $t$ under the Jones (1991) model. SEC is the Financial Secrecy Index from Tax Justice Network (2015). IFRS takes the value of 1 from the second year of adoption and the value 0 in the years before adoption. BIG_4 takes the value of 1 if the auditor is a Big 4 auditor (Deloitte, Ernst Young, KPMG, and PWC) and 0 , otherwise. INV is investor protection as indicated by five different measures (1) JUD is the judicial independence scores from World Economic Forum (2015), (2) MIN is the protection of minority shareholders' interest scores from World Economic Forum (2015), (3) 
$R S E$ is the regulation of securities laws scores from World Economic Forum (2015), (4) IIPB is the irregular payment and bribes scores from World Economic Forum (2015), and (5) FTEM is the financing through local equity market scores from World Economic Forum (2015). Controls are: $L N \_S A L E S$ is natural logarithm of total sales of firm $i$ in year $t$. $F \_L E V$ is the end of year total long term debt divided by end of year shareholders' equity of firm $i$ in year $t$. $S \_G W T H$ is the sales growth rate, defined as the sales in current year minus sales in prior year and divided by sales in prior year for firm $i$ in year $t . \Delta \mathrm{PPE}$ is the growth rate of gross PPE, defined as the gross PPE in current year minus the gross PPE in prior year and divided by the gross PPE in prior year for firm $i$ in year $t$. CFO is the operating cash flows for firm $i$ in year $t$ scaled by total assets. LOSS takes the value of 1 if firm $i$ in year $t$ reports negative income before extraordinary items and 0 otherwise. Fixed effects are (i) Industry dummies, a vector of dummy variables indicating industry sector membership. (ii) Year dummies, a vector of dummy variables indicating Year. 


\section{Table 7}

\section{Alternative measure for secrecy}

Ab_Accruals $_{i t}=\beta_{0}+\beta_{1} P O L \_S Y S+\beta_{2} I F R S+\beta_{3} P O L \_S Y S * I F R S+\beta_{4} B I G \_4+\beta_{5} I N V+$ $\beta_{6} L N \_S A L E S_{i t}+\beta_{7} F_{-} L E V_{i t}+\beta_{8} S_{-} G W T H_{i t}+\beta_{9} \triangle P P E_{i t}+\beta_{10} C F O_{i t}+\beta_{11} L A G L O S S_{i t}+$ fixed effects

\begin{tabular}{|c|c|c|c|c|c|}
\hline $\begin{array}{l}\text { Independent } \\
\text { variables }\end{array}$ & $\mathrm{INV}=\mathrm{JUD}$ & $\mathrm{INV}=\mathrm{MIN}$ & $\mathrm{INV}=\mathrm{RSE}$ & $\mathrm{INV}=\mathrm{IIPB}$ & $\begin{array}{l}\text { INV = } \\
\text { FTEM }\end{array}$ \\
\hline & Estimate & Estimate & Estimate & Estimate & Estimate \\
\hline & (p-value) & (p-value) & (p-value) & (p-value) & (p-value) \\
\hline Intercept & $0.0047^{* * *}$ & $0.0046^{* * *}$ & $0.0045^{* * *}$ & $0.0044^{* * *}$ & $0.0040^{* * *}$ \\
\hline & $(0.000)$ & $(0.000)$ & $(0.000)$ & $(0.004)$ & $(0.000)$ \\
\hline POL_SYS & $0.0012^{* * * *}$ & $0.0014^{* * *}$ & $0.0014^{* * *}$ & $0.0012^{* * * *}$ & $0.0012^{* * *}$ \\
\hline & $(0.000)$ & (0.000) & $(0.001)$ & $(0.001)$ & $(0.000)$ \\
\hline IFRS & -0.0001 & $-0.0010^{* *}$ & -0.0000 & $-0.0007^{*}$ & $-0.0012^{* *}$ \\
\hline & (1) & $(0.042)$ & (0289) & $(0.068)$ & $(0.021)$ \\
\hline$P O L \_S Y S * I F R S$ & $-0.0014^{* * *}$ & $-0.0015^{* * *}$ & $-0.0014^{* * * *}$ & $-0.0014^{* * *}$ & $-0.0015^{* * *}$ \\
\hline & $00)$ & $(0.000)$ & $(0.000)$ & $(0.000)$ & $(0.002)$ \\
\hline$B I G_{-} 4$ & -0.0032 & $-0.0131^{*}$ & -0.0001 & $-0.0198^{* *}$ & -0.0000 \\
\hline & $(0.128)$ & $(0.081)$ & $(0.229)$ & $(0.026)$ & $(0.398)$ \\
\hline$I N V$ & $-0.0068^{* * *}$ & $-0.0076^{* * *}$ & $-0.0078^{* * *}$ & $-0.0076^{* * *}$ & $-0.0072^{* * *}$ \\
\hline & $(0.000)$ & $(0.000)$ & $(0.001)$ & $(0.001)$ & $(0.001)$ \\
\hline Controls & Yes & Yes & Yes & Yes & Yes \\
\hline Fixed effects & Yes & Yes & Yes & Yes & Yes \\
\hline Adjusted $\mathrm{R}^{2}$ & $19.16 \%$ & $20.18 \%$ & $20.58 \%$ & $21.10 \%$ & $19.56 \%$ \\
\hline $\mathrm{N}$ & 24,034 & 24,034 & 24,034 & 24,034 & 24,034 \\
\hline
\end{tabular}

Note: Coefficient p-values applied two-tail and based on asymptotic Z-statistic robust to heteroscedasticity and country clustering effects using the method in Rogers (1993). 
Ab_Accruals is the signed abnormal accruals of firm $i$ in year $t$ under the DeFond and Park (2001) model (Francis and Wang 2008 and Houqe et al., 2012). POL_SYS is the complement of the Political System score from Democracy Ranking (2014). IFRS takes the value of 1 from the second year of adoption and the value 0 in the years before adoption. $B I G \_4$ takes the value of 1 if the auditor is a Big 4 auditor (Deloitte, Ernst Young, KPMG, and PWC) and 0 , otherwise. $I N V$ is investor protection as indicated by five different measures (1) JUD is the judicial independence scores from World Economic Forum (2015), (2) MIN is the protection of minority shareholders' interest scores from World Economic Forum (2015), (3) RSE is the regulation of securities laws scores from World Economic Forum (2015), (4) IIPB is the irregular payment and bribes scores from World Economic Forum (2015), and (5) FTEM is the financing through local equity market scores from World Economic Forum (2015). Controls are: $L N \_S A L E S$ is natural logarithm of total sales of firm $i$ in year $t . F \_L E V$ is the end of year total long term debt divided by end of year shareholders' equity of firm $i$ in year t. S_GWTH is the sales growth rate, defined as the sales in current year minus sales in prior year and divided by sales in prior year for firm $i$ in year $t . \triangle \mathrm{PPE}$ is the growth rate of gross PPE, defined as the gross PPE in current year minus the gross PPE in prior year and divided by the gross PPE in prior year for firm $i$ in year $t$. CFO is the operating cash flows for firm $i$ in year $t$ scaled by total assets. LOSS takes the value of 1 if firm $i$ in year $t$ reports negative income before extraordinary items and 0 otherwise. Fixed effects are (i) Industry dummies, a vector of dummy variables indicating industry sector membership. (ii) Year dummies, a vector of dummy variables indicating Year. 


\section{Table 8}

\section{Other institutional changes}

$A b_{-}$Accruals $_{i t}=\beta_{0}+\beta_{1} S E C+\beta_{2}$ IFRS $+\beta_{3}$ SEC ${ }^{*} I F R S+\beta_{4}$ BIG_4 $+\beta_{5}$ ENFORC + $\beta_{6} L N \_S A L E S_{i t}+\beta_{7} F_{-} L E V_{i t}+\beta_{8} S_{-} G W T H_{i t}+\beta_{9} \triangle P P E_{i t}+\beta_{10} C F O_{i t}+\beta_{11} L A G L O S S_{i t}+$ fixed effects

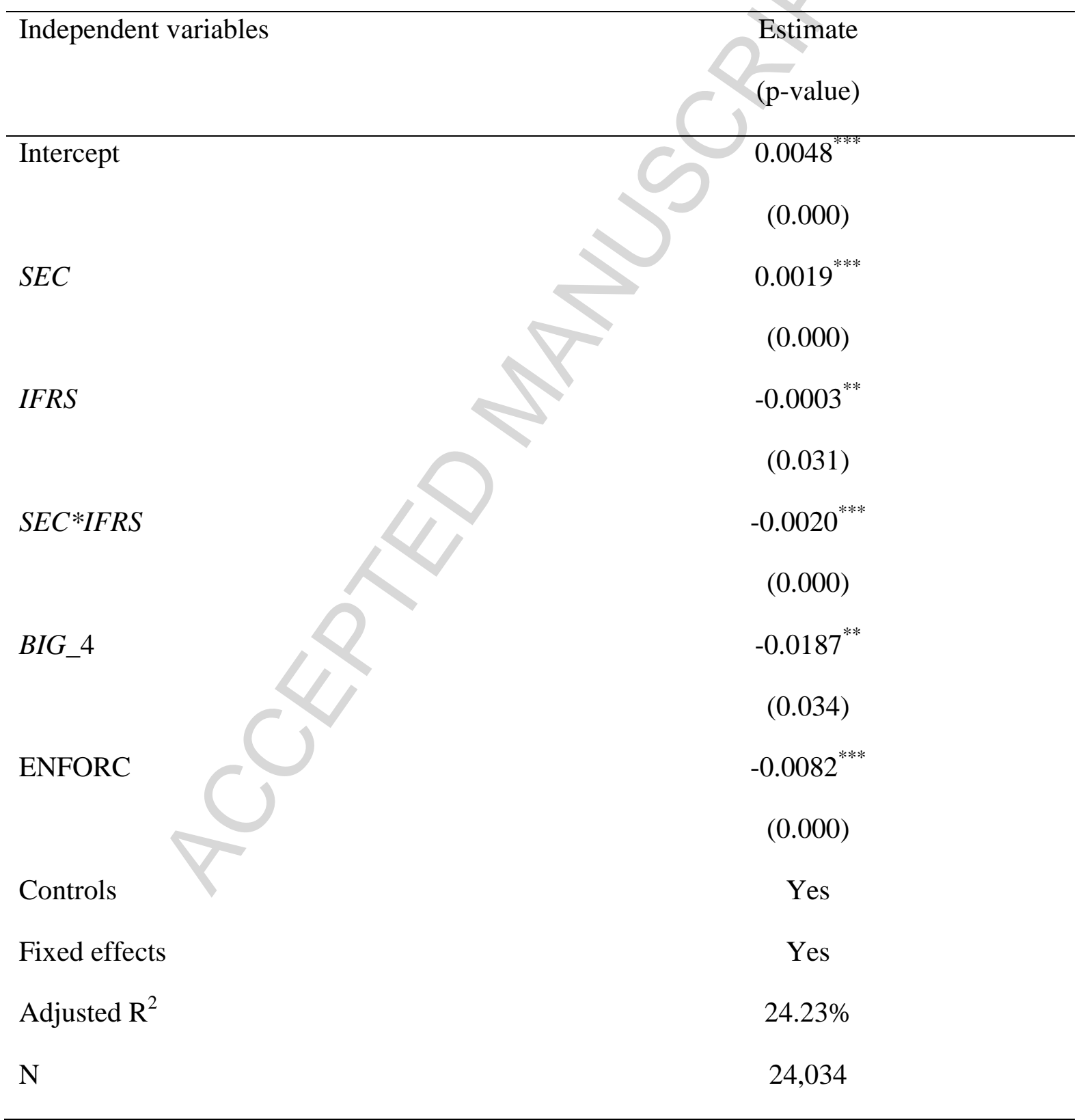

Note: Coefficient p-values applied two-tail and based on asymptotic Z-statistic robust to heteroscedasticity and country clustering effects using the method in Rogers (1993). 
$A b \_$Accruals is the signed abnormal accruals of firm $i$ in year $t$ under DeFond and Park (2001) model (Francis and Wang 2008 and Houqe et al., 2012). SEC is the Financial Secrecy Index from Tax Justice Network (2015). IFRS takes the value of 1 from the second year of adoption and the value 0 in the years before adoption. $B I G_{-} 4$ takes the value of 1 if the auditor is a Big 4 auditor (Deloitte, Ernst Young, KPMG, and PWC) and 0, otherwise. ENFORC is the enforcement index from Brown et al (2014) set equal to the 2002 score and the 2008 score for pre and post IFRS adoption observations respectively. Controls are: $L N \_S A L E S$ is natural logarithm of total sales of firm $i$ in year $t . F \_L E V$ is the end of year total long term debt divided by end of year shareholders' equity of firm $i$ in year $t$. S_GWTH is the sales growth rate, defined as the sales in current year minus sales in prior year and divided by sales in prior year for firm $i$ in year $t . \triangle \mathrm{PPE}$ is the growth rate of gross PPE, defined as the gross PPE in current year minus the gross PPE in prior year and divided by the gross PPE in prior year for firm $i$ in year $t$. CFO is the operating cash flows for firm $i$ in year $t$ scaled by total assets. LOSS takes the value of 1 if firm $i$ in year $t$ reports negative income before extraordinary items and 0 otherwise. Fixed effects are (i) Industry dummies, a vector of dummy variables indicating industry sector membership. (ii) Year dummies, a vector of dummy variables indicating Year. 


\section{Table 9}

\section{Subsample 2003-2004 and 2006-2007}

$A b \_$Accruals $_{i t}=\beta_{0}+\beta_{1} S E C+\beta_{2} I F R S+\beta_{3} S E C * I F R S+\beta_{4} B I G_{-} 4+\beta_{5} I N V+\beta_{6} L N_{-} S A L E S_{i t}$ $+\beta_{7} F_{-} L E V_{i t}+\beta_{8} S_{-} G W T H_{i t}+\beta_{9} \triangle P P E_{i t}+\beta_{10} C F O_{i t}+\beta_{11} L O S S_{i t}+$ fixed effects

\begin{tabular}{|c|c|c|c|c|c|}
\hline \multirow[t]{3}{*}{$\begin{array}{l}\text { Independent } \\
\text { variables }\end{array}$} & $\mathrm{INV}=\mathrm{JUD}$ & $\mathrm{INV}=\mathrm{MIN}$ & $\mathrm{INV}=\mathrm{RSE}$ & $\mathrm{INV}=\mathrm{IIPB}$ & $\begin{array}{l}\text { INV = } \\
\text { FTEM }\end{array}$ \\
\hline & Estimate & Estimate & Estimate & Estimate & Estimate \\
\hline & (p-value) & (p-value) & (p-value) & (p-value) & (p-value) \\
\hline \multirow[t]{2}{*}{ Intercept } & $0.0038^{* * * *}$ & $0.0039^{* * * *}$ & $0.0036^{* * * *}$ & $0.0038^{* * * *}$ & $0.0037^{* * * *}$ \\
\hline & $(0.000)$ & $(0.000)$ & $(0.001)$ & $(0.002)$ & $(0.008)$ \\
\hline \multirow[t]{2}{*}{$S E C$} & $0.0017^{* * *}$ & 0.0016 & $0.0018^{* * *}$ & $0.0016^{* * *}$ & $0.0015^{* * *}$ \\
\hline & $(0.000)$ & $(0.000)$ & $(0.001)$ & $(0.001)$ & $(0.000)$ \\
\hline \multirow[t]{2}{*}{ IFRS } & $-0.0004^{*}$ & & $-0.0006^{* *}$ & 0.0000 & $-0.0002^{*}$ \\
\hline & $(0.051$ & $(0.080)$ & $(0.021)$ & $(0.587)$ & (0.093) \\
\hline \multirow[t]{2}{*}{$S E C^{*} I F R S$} & $-0.0019^{* * *}$ & $-0.0018^{* * *}$ & $-0.0021^{* * *}$ & $-0.0018^{* * *}$ & $-0.0017^{* * * *}$ \\
\hline & $(0.000)$ & $(0.001)$ & $(0.000)$ & $(0.000)$ & $(0.002)$ \\
\hline \multirow[t]{2}{*}{$B I G_{-} 4$} & $-0.0044^{*}$ & 0.0024 & $-0.0128^{* *}$ & $-0.0048^{* *}$ & -0.0001 \\
\hline & $0.051)$ & $(0.228)$ & $(0.011)$ & $(0.050)$ & $(0.368)$ \\
\hline \multirow[t]{2}{*}{$I N V$} & $-0.0085^{* * *}$ & $-0.0088^{* * *}$ & $-0.0082^{* * *}$ & $-0.0081^{* * *}$ & $-0.0085^{* * *}$ \\
\hline & $(0.001)$ & $(0.000)$ & $(0.000)$ & $(0.001)$ & $(0.000)$ \\
\hline Controls & Yes & Yes & Yes & Yes & Yes \\
\hline Fixed effects & Yes & Yes & Yes & Yes & Yes \\
\hline Adjusted $\mathrm{R}^{2}$ & $20.24 \%$ & $19.21 \%$ & $20.14 \%$ & $20.96 \%$ & $22.28 \%$ \\
\hline $\mathrm{N}$ & 4,256 & 4,256 & 4,256 & 4,256 & 4,256 \\
\hline
\end{tabular}

Note: Coefficient p-values applied two-tail and based on asymptotic Z-statistic robust to heteroscedasticity and country clustering effects using the method in Rogers (1993). 
Ab_Accruals is the signed abnormal accruals of firm $i$ in year $t$ under DeFond and Park (2001) model (Francis and Wang 2008 and Houqe et al., 2012). SEC is the Financial Secrecy Index from Tax Justice Network (2015). IFRS takes the value of 1 from the second year of adoption and the value 0 in the years before adoption. BIG_4 takes the value of 1 if the auditor is a Big 4 auditor (Deloitte, Ernst Young, KPMG, and PWC) and 0, otherwise. INV is investor protection as indicated by five different measures (1) JUD is the judicial independence scores from World Economic Forum (2015), (2) MIN is the protection of minority shareholders' interest scores from World Economic Forum (2015), (3) RSE is the regulation of securities laws scores from World Economic Forum (2015), (4) IIPB is the irregular payment and bribes scores from World Economic Forum (2015), and (5) FTEM is the financing through local equity market scores from World Economic Forum (2015). Controls are: $L N \_S A L E S$ is natural logarithm of total sales of firm $i$ in year $t . F \_L E V$ is the end of year total long term debt divided by end of year shareholders' equity of firm $i$ in year t. S_GWTH is the sales growth rate, defined as the sales in current year minus sales in prior year and divided by sales in prior year for firm $i$ in year $t . \triangle \mathrm{PPE}$ is the growth rate of gross PPE, defined as the gross PPE in current year minus the gross PPE in prior year and divided by the gross PPE in prior year for firm $i$ in year $t$. $C F O$ is the operating cash flows for firm $i$ in year $t$ scaled by total assets. LOSS takes the value of 1 if firm $i$ in year $t$ reports negative income before extraordinary items and 0 otherwise. Fixed effects are (i) Industry dummies, a vector of dummy variables indicating industry sector membership. (ii) Year dummies, a vector of dummy variables indicating Year. 


\section{Table 10}

\section{Sample excluding UK, France, Germany and the Netherlands}

$A b_{-}$Accruals $_{i t}=\beta_{0}+\beta_{1} S E C+\beta_{2} I F R S+\beta_{3} S E C * I F R S+\beta_{4} B I G_{-} 4+\beta_{5} I N V+\beta_{6} L N \_S A L E S_{i t}$ $+\beta_{7} F_{-} L E V_{i t}+\beta_{8} S_{-} G W T H_{i t}+\beta_{9} \triangle P P E_{i t}+\beta_{10} C F O_{i t}+\beta_{11} L O S S_{i t}+$ fixed effects

\begin{tabular}{|c|c|c|c|c|c|}
\hline \multirow[t]{3}{*}{$\begin{array}{l}\text { Independent } \\
\text { variables }\end{array}$} & $\mathrm{INV}=\mathrm{JUD}$ & $\mathrm{INV}=\mathrm{MIN}$ & $\mathrm{INV}=\mathrm{RSE}$ & $\mathrm{INV}=\mathrm{IIPB}$ & $\begin{array}{l}\text { INV = } \\
\text { FTEM }\end{array}$ \\
\hline & Estimate & Estimate & Estimate & Estimate & Estimate \\
\hline & (p-value) & (p-value) & (p-value) & (p-value) & (p-value) \\
\hline \multirow[t]{2}{*}{ Intercept } & $0.0046^{* * * *}$ & $0.0042^{\text {***** }}$ & $0.0044^{* * *}$ & $0.0046^{* * *}$ & $0.0045^{\text {**** }}$ \\
\hline & $(0.000)$ & $(0.002)$ & $(0.001)$ & $(0.000)$ & $(0.001)$ \\
\hline \multirow[t]{2}{*}{ SEC } & $0.0017^{* * *}$ & $0.0016^{*}$ & $0.0015^{* * *}$ & $0.0014^{* * *}$ & $0.0017^{* * *}$ \\
\hline & $(0.000)$ & $(0.000)$ & (0.001) & $(0.001)$ & $(0.000)$ \\
\hline \multirow[t]{2}{*}{ IFRS } & -0.0000 & 0.0001 & -0.0000 & -0.0001 & $-0.0004^{*}$ \\
\hline & $(0.384)$ & 251) & (0.679) & (0.147) & (0.097) \\
\hline \multirow[t]{2}{*}{$S E C^{*} I F R S$} & -0.0016 & $-0.0017^{* * *}$ & $-0.0016^{* * *}$ & $-0.0015^{* * *}$ & $-0.0017^{* * *}$ \\
\hline & $(0.000)$ & $(0.000)$ & $(0.000)$ & $(0.000)$ & $(0.004)$ \\
\hline \multirow[t]{2}{*}{$B I G \_4$} & $-0.0039^{*}$ & 0.0020 & $-0.0112^{*}$ & $-0.0046^{*}$ & -0.0000 \\
\hline & $(0.087)$ & $(0.298)$ & $(0.056)$ & $(0.076)$ & $(0.578)$ \\
\hline \multirow[t]{2}{*}{$I N V$} & $-0.0076^{* * *}$ & $-0.0078^{* * *}$ & $-0.0076^{* * *}$ & $-0.0082^{* * *}$ & $-0.0080^{* * * *}$ \\
\hline & (0.004) & $(0.002)$ & (0.006) & $(0.000)$ & (0.001) \\
\hline Controls & Yes & Yes & Yes & Yes & Yes \\
\hline Fixed effects & Yes & Yes & Yes & Yes & Yes \\
\hline Adjusted $\mathrm{R}^{2}$ & $17.10 \%$ & $16.96 \%$ & $17.01 \%$ & $17.25 \%$ & $16.85 \%$ \\
\hline $\mathrm{N}$ & 7,286 & 7,286 & 7,286 & 7,286 & 7,286 \\
\hline
\end{tabular}

Note: Coefficient p-values applied two-tail and based on asymptotic Z-statistic robust to heteroscedasticity and country clustering effects using the method in Rogers (1993). 
$A b \_$Accruals is the signed abnormal accruals of firm $i$ in year $t$ under DeFond and Park (2001) model (Francis and Wang 2008 and Houqe et al., 2012). SEC is the Financial Secrecy Index from Tax Justice Network (2015). IFRS takes the value of 1 from the second year of adoption and the value 0 in the years before adoption. $B I G_{-} 4$ takes the value of 1 if the auditor is a Big 4 auditor (Deloitte, Ernst Young, KPMG, and PWC) and 0, otherwise. INV is investor protection as indicated by five different measures (1) JUD is the judicial independence scores from World Economic Forum (2015), (2) MIN is the protection of minority shareholders' interest scores from World Economic Forum (2015), (3) RSE is the regulation of securities laws scores from World Economic Forum (2015), (4) IIPB is the irregular payment and bribes scores from World Economic Forum (2015), and (5) FTEM is the financing through local equity market scores from World Economic Forum (2015). Controls are: $L N \_S A L E S$ is natural logarithm of total sales of firm $i$ in year $t . F \_L E V$ is the end of year total long term debt divided by end of year shareholders' equity of firm $i$ in year t. S_GWTH is the sales growth rate, defined as the sales in current year minus sales in prior year and divided by sales in prior year for firm $i$ in year $t . \triangle \mathrm{PPE}$ is the growth rate of gross PPE, defined as the gross PPE in current year minus the gross PPE in prior year and divided by the gross PPE in prior year for firm $i$ in year $t$. CFO is the operating cash flows for firm $i$ in year $t$ scaled by total assets. LOSS takes the value of 1 if firm $i$ in year $t$ reports negative income before extraordinary items and 0 otherwise. Fixed effects are (i) Industry dummies, a vector of dummy variables indicating industry sector membership. (ii) Year dummies, a vector of dummy variables indicating Year. 


\section{Table 11}

\section{High vs Low Secrecy}

$A b \_$Accruals $_{i t}=\beta_{0}+\beta_{1} S E C+\beta_{2} I F R S+\beta_{3} S E C * I F R S+\beta_{4} B I G_{-} 4+\beta_{5} I N V+\beta_{6} L N \_S A L E S_{i t}$ $+\beta_{7} F_{-} L E V_{i t}+\beta_{8} S_{-} G W T H_{i t}+\beta_{9} \triangle P P E_{i t}+\beta_{10} C F O_{i t}+\beta_{11} L A G L O S S_{i t}+$ fixed effects

\begin{tabular}{|c|c|c|c|c|c|}
\hline \multirow[t]{3}{*}{$\begin{array}{l}\text { Independent } \\
\text { variables }\end{array}$} & $\mathrm{INV}=\mathrm{JUD}$ & $\mathrm{INV}=\mathrm{MIN}$ & $\mathrm{INV}=\mathrm{RSE}$ & $\mathrm{INV}=\mathrm{IIPB}$ & $\begin{array}{l}\text { INV = } \\
\text { FTEM }\end{array}$ \\
\hline & Estimate & Estimate & Estimate & Estimate & Estimate \\
\hline & (p-value) & (p-value) & (p-value) & (p-value) & (p-value) \\
\hline \multirow[t]{2}{*}{ Intercept } & $0.0039^{* * *}$ & $0.0038^{\text {**** }}$ & $0.0037^{\text {**** }}$ & $0.0042^{* * *}$ & $0.0040^{* * *}$ \\
\hline & $(0.000)$ & $(0.001)$ & $(0.000)$ & $(0.001)$ & $(0.006)$ \\
\hline \multirow[t]{2}{*}{$S E C$} & $0.0013^{* * *}$ & $0.0014^{*}$ & $0.0014^{* * *}$ & $0.0013^{* * *}$ & $0.0014^{* * *}$ \\
\hline & $(0.002)$ & $(0.000)$ & $(0.001)$ & $(0.003)$ & $(0.003)$ \\
\hline \multirow[t]{2}{*}{$I F R S$} & -0.0001 & 1 & $-0.0002^{*}$ & 0.0001 & $-0.0003^{* *}$ \\
\hline & $(0.359$ & $(0.569)$ & $(0.078)$ & $(0.347)$ & $(0.041)$ \\
\hline \multirow[t]{2}{*}{$S E C * I F R S$} & $-0.0014^{* * *}$ & $-0.0014^{* * *}$ & $-0.0015^{* * *}$ & $-0.0013^{* * *}$ & $-0.0015^{* * *}$ \\
\hline & $(0.001)$ & $(0.000)$ & $(0.000)$ & $(0.001)$ & $(0.000)$ \\
\hline \multirow[t]{2}{*}{$B I G \_4$} & -0.0010 & 0.0021 & $-0.0148^{* *}$ & 0.0000 & -0.0011 \\
\hline & $(0.241)$ & $(0.198)$ & $(0.041)$ & $(0.654)$ & $(0.114)$ \\
\hline \multirow[t]{2}{*}{$I N V$} & $-0.0084^{* * *}$ & $-0.0080^{* * * *}$ & $-0.0083^{* * *}$ & $-0.0085^{* * *}$ & $-0.0087^{* * *}$ \\
\hline & $(0.000)$ & $(0.002)$ & $(0.000)$ & $(0.000)$ & $(0.000)$ \\
\hline Controls & Yes & Yes & Yes & Yes & Yes \\
\hline Fixed effects & Yes & Yes & Yes & Yes & Yes \\
\hline Adjusted $\mathrm{R}^{2}$ & $16.16 \%$ & $17.26 \%$ & $16.34 \%$ & $17.29 \%$ & $17.39 \%$ \\
\hline $\mathrm{N}$ & 24,034 & 24,034 & 24,034 & 24,034 & 24,034 \\
\hline
\end{tabular}

Note: Coefficient p-values applied two-tail and based on asymptotic Z-statistic robust to heteroscedasticity and country clustering effects using the method in Rogers (1993). 
Ab_Accruals is the signed abnormal accruals of firm $i$ in year $t$ under DeFond and Park (2001) model (Francis and Wang 2008 and Houqe et al., 2012). SEC is the Financial Secrecy Index from Tax Justice Network (2015). IFRS takes the value of 1 from the second year of adoption and the value 0 in the years before adoption. BIG_4 takes the value of 1 if the auditor is a Big 4 auditor (Deloitte, Ernst Young, KPMG, and PWC) and 0, otherwise. INV is investor protection as indicated by five different measures (1) JUD is the judicial independence scores from World Economic Forum (2015), (2) MIN is the protection of minority shareholders' interest scores from World Economic Forum (2015), (3) RSE is the regulation of securities laws scores from World Economic Forum (2015), (4) IIPB is the irregular payment and bribes scores from World Economic Forum (2015), and (5) FTEM is the financing through local equity market scores from World Economic Forum (2015). Controls are: $L N \_S A L E S$ is natural logarithm of total sales of firm $i$ in year $t . F \_L E V$ is the end of year total long term debt divided by end of year shareholders' equity of firm $i$ in year t. S_GWTH is the sales growth rate, defined as the sales in current year minus sales in prior year and divided by sales in prior year for firm $i$ in year $t . \triangle \mathrm{PPE}$ is the growth rate of gross PPE, defined as the gross PPE in current year minus the gross PPE in prior year and divided by the gross PPE in prior year for firm $i$ in year $t$. $C F O$ is the operating cash flows for firm $i$ in year $t$ scaled by total assets. LOSS takes the value of 1 if firm $i$ in year $t$ reports negative income before extraordinary items and 0 otherwise. Fixed effects are (i) Industry dummies, a vector of dummy variables indicating industry sector membership. (ii) Year dummies, a vector of dummy variables indicating Year. 
Highlights

*Effect of mandatory IFRS adoption on earnings quality in high secrecy countries

*Firms in high secrecy countries tend to report lower quality earning

*Mandatory IFRS adoption moderates the effect of secrecy on earnings quality. 


\section{Accepted Manuscript}

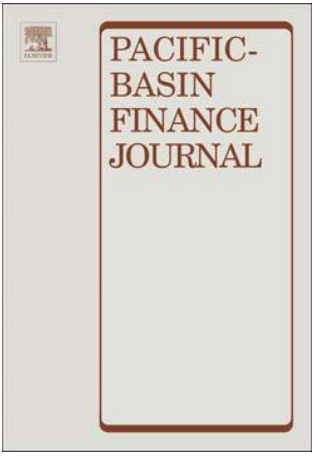

Secrecy and the Impact of Mandatory IFRS Adoption on Earnings Quality in Europe

Muhammad Nurul Houqe, Reza M. Monem, Mohammad Tareq, Tony van Zijl

PII:

S0927-538X(16)30099-3

DOI: $\quad$ doi: $10.1016 /$ j.pacfin. 2016.08 .002

Reference: $\quad$ PACFIN 872

To appear in: $\quad$ Pacific-Basin Finance Journal

Received date: $\quad 24$ February 2016

Revised date: $\quad 7$ August 2016

Accepted date: 15 August 2016

Please cite this article as: Houqe, Muhammad Nurul, Monem, Reza M., Tareq, Mohammad, van Zijl, Tony, Secrecy and the Impact of Mandatory IFRS Adoption on Earnings Quality in Europe, Pacific-Basin Finance Journal (2016), doi: 10.1016/j.pacfin.2016.08.002

This is a PDF file of an unedited manuscript that has been accepted for publication. As a service to our customers we are providing this early version of the manuscript. The manuscript will undergo copyediting, typesetting, and review of the resulting proof before it is published in its final form. Please note that during the production process errors may be discovered which could affect the content, and all legal disclaimers that apply to the journal pertain. 